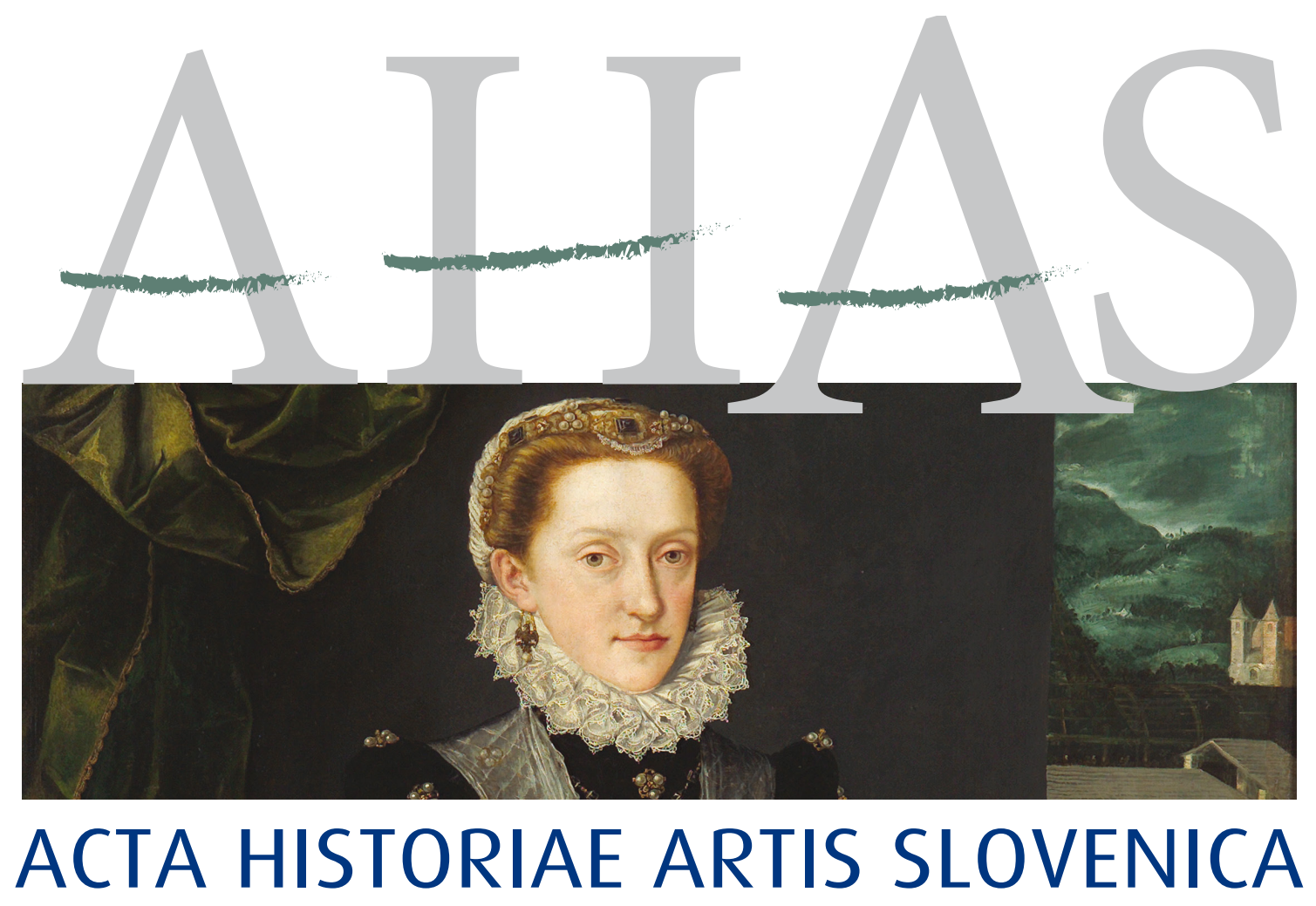

Strategije umetnostne reprezentacije štajerskega plemstva v zgodnjem novem veku

Visual Representation Strategies of the Styrian Nobility in Early Modern Times 


\section{ACTA HISTORIAE ARTIS SLOVENICA $24 \mid 2 \cdot 2019$}

Strategije umetnostne reprezentacije štajerskega plemstva v zgodnjem novem veku

Visual Representation Strategies of the Styrian Nobility in Early Modern Times 
Acta historiae artis Slovenica, 24/2, 2019

Znanstvena revija za umetnostno zgodovino / Scholarly Journal for Art History

ISSN 1408-0419 (tiskana izdaja / print edition) ISSN 2536-4200 (spletna izdaja / web edition)

ISBN je 978-961-05-0245-6

Izdajatelj / Issued by

ZRC SAZU, Umetnostnozgodovinski inštitut Franceta Steleta /

ZRC SAZU, France Stele Institute of Art History

Založnik / Publisher

Založba ZRC

Glavna urednica / Editor-in-chief

Tina Košak

Urednici številke / Edited by

Tina Košak, Polona Vidmar

Uredniški odbor / Editorial board

Renata Komić Marn, Tina Košak, Katarina Mohar, Mija Oter Gorenčič, Blaž Resman, Helena Seražin

Mednarodni svetovalni odbor / International advisory board

Günter Brucher (Salzburg), Ana María Fernández García (Oviedo), Iris Lauterbach (München),

Hellmut Lorenz (Wien), Milan Pelc (Zagreb), Sergio Tavano (Gorizia-Trieste), Barbara Wisch (New York)

Lektoriranje / Language editing

Maria Bentz, Aleksandra Čehovin, Kirsten Hempkin, Amy Anne Kennedy

Prevodi / Translations

Nika Vaupotič, Polona Vidmar

Oblikovna zasnova in prelom / Design and layout

Andrej Furlan

Naslov uredništva / Editorial office address

Acta historiae artis Slovenica

Novi trg 2, p. p. 306, SI - 1001 Ljubljana, Slovenija

E-pošta / E-mail: ahas@zrc-sazu.si

Spletna stran / Web site: http://uifs1.zrc-sazu.si

Revija je indeksirana $v$ / Journal is indexed in

Scopus, ERIH PLUS, EBSCO Publishing, IBZ, BHA

Letna naročnina / Annual subscription: $35 €$

Posamezna enojna številka / Single issue: $25 €$

Letna naročnina za študente in dijake: $25 €$

Letna naročnina za tujino in ustanove / Annual subscription outside Slovenia, institutions: $48 €$

Naročila sprejema / For orders contact

Založba ZRC

Novi trg 2, p. p. 306, SI-1001, Slovenija

E-pošta / E-mail: zalozba@zrc-sazu.si

AHAS izhaja s podporo Javne agencije za raziskovalno dejavnost Republike Slovenije.

AHAS is published with the support of the Slovenian Research Agency.

(c) 2019, ZRC SAZU, Umetnostnozgodovinski inštitut Franceta Steleta, Založba ZRC, Ljubljana

Tisk / Printed by Tiskarna PRESENT d.o.o., Ljubljana

Naklada / Print run: 400 


\section{VSEBINA \\ Contents}

Polona Vidmar

Strategije umetnostne reprezentacije štajerskega plemstva v zgodnjem novem veku. Predgovor 5

Visual Representation Strategies of the Styrian Nobility in Early Modern Times. Preface 7

\section{DISSERTATIONES}

\section{Susanne König-Lein}

Die Porträtsammlungen in der Grazer Burg und im Schloss Karlau im 17. und 18. Jahrhundert

Portretni zbirki v graškem dvoru in dvorcu Karlau v 17. in 18. stoletju

Polona Vidmar

Theatrum genealogicum. Die Stammbäume der Grafen Herberstein und Dietrichstein als Mittel adeliger Repräsentation.

Theatrum genealogicum. Rodovniki grofov Herberstein in Dietrichstein

kot sredstvo plemiške reprezentacije

Renata Komić Marn

Portreti Eleonore Marije Rozalije kneginje Eggenberg, rojene princese Liechtenstein

Portraits of Eleonora Maria Rosalia Princess of Eggenberg, née Liechtenstein

\section{Edgar Lein}

Contraphe der abgeleibten fürstlichen Bischöff zu Seccau. Zur Porträtgalerie

der Seckauer Bischöfe in Schloss Seggau

Contraphe der abgeleibten fürstlichen Bischöff zu Seccau. K portretni galeriji

sekovskih škofov v gradu Seggau

\section{Marjeta Ciglenečki}

Franz Ignaz Count of Inzaghi, Ptuj Parish Archpriest and Dean, and the Veneration of St Victorinus, First Bishop of Poetovio Known by Name.

Franc Ignac grof Inzaghi, ptujski nadžupnik in dekan ter češčenje sv. Viktorina,

prvega po imenu znanega petovionskega škofa

Franci Lazarini

Grofje Brandis - umetnostni naročniki na Štajerskem 


\section{APPARATUS}

Izvlečki in ključne besede /Abstracts and keywords 195

Sodelavci / Contributors

Viri ilustracij/ Photographic credits 


\section{Predgovor}

\section{STRATEGIJE UMETNOSTNE REPREZENTACIJE ŠTAJERSKEGA PLEMSTVA V ZGODNJEM NOVEM VEKU}

Prispevki v tematski številki revije Acta historae artis Slovenica so eden od rezultatov raziskovalnega projekta Umetnostna reprezentacija plemstva. Naročništvo na Štajerskem $v$ zgodnjem novem veku (J6-7410), ki ga je med 1. 1. 2016 in 31. 12. 2018 iz državnega proračuna financirala Javna agencija za raziskovalno dejavnost Republike Slovenije. $\mathrm{Z}$ raziskavami, ki so potekale na Oddelku za umetnostno zgodovino Filozofske fakultete Univerze v Mariboru in Umetnostnozgodovinskem inštitutu Franceta Steleta ZRC SAZU, smo z različnih vidikov osvetlili umetniško reprezentacijo plemstva v zgodnjem novem veku na območju historične Štajerske in v širšem slovenskem prostoru. Z namenom preseganja sedanjih državnih meja so bili v projekt vključeni tudi strokovnjaki iz Gradca, nekdanje deželne prestolnice. Temeljno premiso, da je imelo plemstvo ključno vlogo v novoveškem umetnostnem razvoju dežele, smo obravnavali s preučevanjem vzorcev in strategij, s katerimi se je novoveško plemstvo z naročništvom, mecenstvom in zbirateljstvom oziroma skozi arhitekturo in likovno umetnost reprezentiralo na deželni ravni ter v Habsburški monarhiji.

Raziskave so bile usmerjene v ožji krog naročnikov, ki so se v spreminjajočih se zgodovinskih okoliščinah od 16. do 18. stoletja izkazali z ambicioznostjo v kakovosti in številu naročenih umetniških del ter pogostostjo rabe arhitekture, likovne in uporabne umetnosti za namene reprezentiranja tako v posvetnem kot v sakralnem kontekstu. Preučevanje strategij umetnostne reprezentacije novoveškega štajerskega plemstva pa je bilo $\mathrm{z}$ raziskavami zbirateljstva in naročništva nadvojvodinje Marije Bavarske razširjeno na Habsburžane in z graditeljstvom in naročništvom grofov Brandis kronološko tudi na 19. stoletje. Preučevanje izbranih umetnostnih del v kontekstu sorodstvenih, političnih in diplomatskih povezav naročnikov, njihove izobrazbe in odnosa do vzornikov je temeljilo na raziskavi zapuščinskih inventarjev in inventarjev plemiških rezidenc, kronik, historiografskih in slavilnih besedil. Preučena je bila vloga šolanja, razgledanosti, pobožnosti, vojaške in dvorne službe, preučeni so bili načini naročanja in zbiranja ter možnosti, s katerimi so si naročniki skozi umetnost oblikovali družbeni položaj in si zagotovili trajen spomin. Analizirane so bile specifične strategije posameznih plemičev in pomen umetnosti za uveljavljanje ambicioznih posameznikov.

Študije šestih avtorjev prinašajo nova spoznanja o umetnosti historične Štajerske. Uvaja jih prispevek Susanne König-Lein o portretnih galerijah na graškem dvoru in v dvorcu Karlau pri Gradcu, ki sta jih v drugi polovici 16. stoletja naročila in zbrala nadvojvoda Karel II. in nadvojvodinja Marija Bavarska. Serije družinskih portretov, zlasti otrok, ki so imele genealoško in reprezentativno vlogo, saj so ponazarjale in poveličevale dinastične povezave, so prvič analizirane na podlagi inventarjev in popisov. Galerije družinskih portretov, portretov prednikov in rimskih cesarjev so postavljene v kontekst zbirk v gradu Ambras, Münchnu in Pragi. Odražale so stremljenje k povzdignitvi habsburške dinastije in vizualizaciji njene enakovrednosti z antičnimi vladarji. V drugem prispevku avtorica obravnava slike in grafike rodovnikov rodbin Herberstein in Dietrichstein, ki so nastale $\mathrm{v}$ 17. in 19. stoletju. Vizualizacije genealogij so postavljene $\mathrm{v}$ kontekst portretnih galerij in sočasnih 
zgodovinskih del, ki so bila publicirana po naročilu obravnavanih plemiških rodbin, pri čemer je poudarjena njihova reprezentativna vloga. Prispevek prinaša nove ugotovitve o historiografih, ki so po naročilu plemstva publicirali genealoška dela in snovali likovne upodobitve genealoškega vedenja, zlasti o cesarskem historiografu Dominiku Frančišku Kalinu. Renata Komić Marn obravnava portrete Eleonore Marije Rozalije kneginje Eggenberg, hčere pomembnega naročnika, zbiratelja in pisca Karla Evzebija kneza Liechtensteina. Študija je rezultat raziskav o identifikaciji, provenienci, času nastanka in avtorstvu kneginjinih portretov, posebna pozornost je namenjena javnemu delovanju portretiranke in njenemu morebitnemu vplivu na umetnostna naročila v dvorcu Eggenberg pri Gradcu. Portretom se je posvetil tudi Edgar Lein, ki je v študiji o galeriji sekovskih škofov v gradu Seggau pri Lipnici na podlagi inventarjev raziskal zlasti spreminjajočo se namestitev portretov in domnevnega snovalca galerije. Medtem ko so portreti v posvetnih prostorih odražali dinastične in rodbinske povezave, stremljenje $\mathrm{k}$ ugledu in moči rodbine ter socialne aspiracije naročnikov, je avtor škofovske portrete postavil v kontekst drugih sočasnih škofovskih galerij in poudaril težnjo škofov po legitimiranju svojega položaja in reprezentaciji. Kot temeljne koncepte tovrstnih galerij je prepoznal tradicijo, nasledstvo in memorio. Študija Marjete Ciglenečki prinaša nova spoznanja o naročilih ptujskega nadžupnika in dekana Franca Ignaca grofa Inzaghija in njegovem vplivu na baročno podobo cerkve sv. Jurija. Ko se je izobraženi Inzaghi sredi 18. stoletja intenzivno posvetil uvajanju češčenja sv. Viktorina, je bilo védenje o življenju in delovanju prvega po imenu znanega škofa v poznoantičnem Poetoviu veliko bolj pomanjkljivo, kot je danes. Zato avtorica novo ikonografsko interpretacijo stropne poslikave $v$ kapeli Žalostne Matere božje uvede s podrobno analizo poznoantičnega in zgodnjesrednjeveškega krščanstva na Ptuju, zgodovino cerkve sv. Jurija in češčenja sv. Viktorina. Prispevek Francija Lazarinija predstavlja prvi pregled umetnostnega naročništva grofov Brandis na Štajerskem. S poudarkom na naročniško najaktivnejših rodbinskih članih analizira njihova arhitekturna naročila, zlasti barokizacijo mariborskega mestnega gradu in dvorca Betnava ter temeljito prezidavo dvorca Slivnica.

Preučevanje naročništva in umetnostne reprezentacije je doprineslo k poglobljenemu razumevanju družbene vloge umetnostnih del, s katerimi je plemstvo izražalo svoj družbeni položaj, moč in ugled rodbine, težnje po dvigu socialnega statusa, v primeru naročnikov cerkvenega stanu pa tudi identiteto in ugled ustanove, $v$ kateri so delovali. V pričujočih študijah so posebej izpostavljeni naročila portretov in portretnih galerij, vizualizacije genealoškega vedenja in upodobitve svetnikov, ki so povzdigovali identiteto prostora, ter modernizacije plemiških rezidenc. Želeti je, da bodo študije spodbudile nadaljnje raziskave tega področja.

Polona Vidmar, vodja projekta in gostujoča urednica 


\section{Preface}

\section{Visual RePRESENTATION STRATEgIES OF THE Styrian Nobility in Early Modern Times}

The present thematic issue of Acta historae artis Slovenica is one of the outcomes of the research project Visual Representations of the Nobility: Early Modern Art Patronage in the Styria Province, funded by the Slovenian Research Agency between $1^{\text {st }}$ January 2016 and 31 ${ }^{\text {st }}$ December 2018. The research, conducted by the Department of Art History of the Faculty of Arts, University of Maribor and the France Stele Institute of Art History ZRC SAZU, has shed light from a variety of perspectives on early modern visual representations of the nobility in historical Styria and beyond. In order to transcend current state borders, the project team worked closely with experts from Graz, the former state capital. The team's fundamental hypothesis-that the nobility played a key role in the artistic development of the country in Early Modern Times-was tested by studying the models and strategies with which the nobility represented itself through commissions, patronage and collecting, or through architecture and art, at both state level and within the wider Habsburg Monarchy.

The research was focused on selected cases of aristocratic patrons, who, in the changing historical circumstances between the $16^{\text {th }}$ and $18^{\text {th }}$ century, distinguished themselves with their ambition, expressed in the sheer quality and number of the artworks they commissioned and the frequency with which they used architecture, visual and decorative arts for the purpose of representation, in both secular and religious contexts. By researching the collecting and patronage of Archduchess Maria of Bavaria, research on the early modern artistic representation strategies of Styrian nobility was widened to include the Habsburg family, while by researching the architectural commissions and patronage of the Counts of Brandis, it was also chronologically expanded to include the $19^{\text {th }}$ century. Selected case studies emphasised the role of family relations, the political and diplomatic connections of the patrons, their education and relation to their role models. These studies were based on the research of probate inventories and the inventories of noble residences, chronicles, and historiographical and celebratory texts. The roles of education, knowledge, piety, military and court service have been studied, as well as commissioning and collecting patterns, and the ways in which patrons established their social position and ensured they were remembered through art. The specific strategies of individual noblemen and the importance of art in the establishment of ambitious individuals have also been analysed.

The studies of six authors have refreshed research on the art of historical Styria. First is the paper by Susanne König-Lein on the portrait galleries at the court in Graz and in Karlau Manor near Graz, which were commissioned and collected by Archduke Charles II and Archduchess Maria of Bavaria in the second half of the $16^{\text {th }}$ century. Portrait series, especially portraits of children, which played both genealogical and representative roles, since they illustrated and glorified dynastic connections, are analysed for the first time based on inventories and lists. The galleries of family portraits, portraits of ancestors and Roman Emperors are placed in the context of the collections in Ambras Castle, Munich and Prague. They reflected the ambitions of the Habsburg dynasty and the visualization of its equivalence with ancient rulers. In the second paper, Polona Vidmar discusses 
the paintings and graphics of the genealogies of the Herberstein and Dietrichstein families which were produced in the $17^{\text {th }}$ and $19^{\text {th }}$ centuries. The visualizations of the genealogies commissioned by the noble families are discussed in the context of portrait galleries and concurrent historical works, with emphasis on their representative role. The paper also presents new findings on historiographers, who were commissioned by the nobility to publish genealogical works and artistic representations; particular attention is paid to the Emperor's historiographer Dominicus Franciscus Calin. Renata Komić Marn addresses the portraits of Eleonora Maria Rosalia Princess of Eggenberg, the daughter of an important patron, collector and writer, Karl Eusebius Prince of Liechtenstein. The study is the result of research into the identification, provenance, time of origin and the authorship of the portraits of the princess, while attention is paid to her public deeds and possible influence on the commissioning of art at Eggenberg Palace near Graz. Edgar Lein also focuses on portraits. In a study of the portrait gallery of the Seckau bishops at Seggau Castle near Leibnitz, he focused on the changing placement of the portraits and the presumed founder of the gallery, based on the inventories. While the portraits reflected the families' striving for reputation, their dynastic and family connections and their power, as well as the social aspirations of the commissioners, the author has placed portraits of bishops in the context of concurrent bishops' galleries, highlighting their aspirations for the legitimization of their position and representation. He identified tradition, succession and memoria as the fundamental concepts underpinning such galleries. The article by Marjeta Ciglenečki expands research on the commissions by the Ptuj archpriest and dean Franz Ignaz Count of Inzaghi and his influence on the Baroque furnishings of the church of St George. When in the middle of the $18^{\text {th }}$ century, the educated Inzaghi dedicated himself to introducing the veneration of St Victorinus, little was known of the life and work of the first bishop known by name in Late-Antique Poetovio. The author presents a new iconographic interpretation of the ceiling painting in the chapel of Our Lady of Sorrows through a thorough analysis of Christianity in Ptuj in Late Antiquity and the Early Middle Ages, the history of the church of St George and the veneration of St Victorinus. The paper by Franci Lazarini is the first overview of the art patronage of the Counts of Brandis in Styria. Focusing on the family members who were most active as patrons, he analyses their architectural commissions, especially the Baroquization of Maribor Town Castle and Betnava Mansion as well as the thorough reconstruction of Slivnica Manor.

This research into patronage and artistic representation of the nobility has contributed to a more thorough understanding of the social role of the artworks with which the nobility expressed their social position, the power and reputation of their families, their aspirations for the elevation of their social position, and in the case of religious patrons, also the identity and the reputation of the institution for whom they worked. The following studies focus particularly on the commissioning of portraits and portrait galleries, visualizations of genealogical knowledge and depictions of saints, which elevated the identity of the space, and the modernization and construction of noble residences. It is our hope that these studies will encourage further research in this area.

Polona Vidmar, project leader and guest editor 
DISSERTATIONES 


\section{Grofje Brandis - umetnostni naročniki na Štajerskem}

\section{Franci Lazarini}

Grofje Brandis sodijo med plemiške rodbine, ki so bile v dosedanjih raziskavah plemstva in njegovega umetnostnega naročništva na Slovenskem skoraj popolnoma spregledane, pa čeprav gre za rodbino, ki je v 18., pa tudi še v 19. stoletju, torej celo v času, ko je moč plemstva začela upadati, vplivala na podobo marsikaterega pomembnega umetnostnega spomenika na Štajerskem. Sama zgodovina rodbine Brandis je sicer dobro raziskana in je bila že konec 19. stoletja objavljena v obsežni monografiji Ferdinanda grofa Brandisa (1847-1917); ${ }^{1}$ slednja temelji zlasti na gradivu iz njihovega zasebnega rodbinskega arhiva. ${ }^{2}$ Prav tako je rodbina obravnavana v večini relevantnih leksikalnih del, ${ }^{3}$ drugače pa je s študijami njihovega umetnostnega naročništva, saj to ni raziskano niti za preostale habsburške dežele, v katerih so delovali, v prvi vrsti za njihovo domovino Tirolsko, kar nedvomno otežuje raziskovanje umetnostnega delovanja grofov Brandis v naših krajih. V nekaterih starejših obravnavah z rodbino Brandis povezanih umetnostnih spomenikov na Štajerskem so bili posamezni predstavniki rodbine sicer omenjeni, vendar je pri tem pogosto prihajalo do genealoških napak in nedoslednosti. Stanje se je nekoliko spremenilo v zadnjih letih, ko so izšli trije prispevki, ki so se prvič dotaknili njihove naročniške vloge na Štajerskem. Tako je avtor tega prispevka z vidika umetnostnega naročništva predstavil Klemena grofa Brandisa, enega najvidnejših družinskih članov $\mathrm{v}$ predmarčni dobi, pri čemer so bila predstavljena tako njegova naročila $\mathrm{v}$ slovenskem prostoru kot tudi na Tirolskem in Češkem, ${ }^{4}$ Tina Košak je analizirala Brandisovo zbirko slik, ki je bila nekoč v

1 Ferdinand Graf von BRANDIS, Das Familienbuch der Grafen von Brandis, Baden bei Wien 1889. Delo obravnava družinsko zgodovino od srednjega veka do šestdesetih let 19. stoletja. Genealoški podatki iz navedenega dela so dopolnjeni po: Steiermärkisches Landesarchiv Graz (StLA), Lazarini, Familie, K. 7, H. 162, Brandis, rodovnik rodbine Brandis; Zgodovinski arhiv Ljubljana (ZAL), SI ZAL LJU/0340, Zbirka plemiških genealogij Ludvika Lazarinija, šk. 5, Brandis; Johann Baptist WITTING, J. Siebmacher's grosses und allgemeines Wappenbuch. IV/7: Steiermärkischer Adel, Nürnberg 1919-1921, stp. 282-291.

2 Arhiv rodbine Brandis je v njihovi zasebni lasti na gradu Leonburg.

3 Npr. Constantin von WURZBACH, Brandis, Biographisches Lexikon des Kaiserthums Österreich, 2, Wien 1857 (reprint: Bad Fellnbach 2001), str. 114; Brandis, Grafen, Neues allgemeines Deutsches Adels-Lexicon (ur. Ernst Heinrich Kneschke), 2, Leipzig 1860, str. 17-18; Brandis (Tirol), Adelslexikon (ur. Walter v. Hueck), 2, Limburg an der Lahn 1974 (Genealogisches Handbuch des Adels, 58), str. 62. O pomenu in zaslugah rodbine Brandis, zlasti za Tirolsko, gl. Josef HIRN, Die Entwicklung der Landeshauptmannswürde in Tirol und die Familie Brandis, Innsbruck 1892. V zadnjem času je grofe Brandis kot lastnike mariborskega mestnega gradu na kratko obravnaval tudi Sašo Radovanovič (Sašo RADOVANOVIČ, Zakupniki in lastniki mariborskega mestnega gradu od leta 1483 do 2006, Podravina, 6/11, 2007, str. 162), a ima besedilo, zlasti kar se začetkov Brandisov na Štajerskem tiče, nekaj napak.

4 Franci LAZARINI, Klemen grof Brandis - politik in umetnostni naročnik, Acta historiae artis Slovenica, 21/1, 2016, str. 75-91. 
dvorcu Betnava, ${ }^{5}$ Simona Kostanjšek Brglez je v sklopu obravnave ponovno odkritih slik Leopolda Kupelwieserja (1796-1862) iz profanirane kapele dvorca Slivnica izpostavila povezavo med grofi Brandis in slikarjem. ${ }^{6}$ Pričujoči prispevek pa predstavlja prvi (in brez dvoma nepopolni) pregled umetnostnega naročništva rodbine Brandis na Štajerskem, s posebnim poudarkom na naročniško najbolj aktivnih rodbinskih članih.

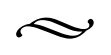

Prvi arhivski zapis, ki se nesporno nanaša na pripadnike rodbine Brandis, izvira iz leta 1172, ko sta v neki listini samostana Schäftlarn na Bavarskem kot priči omenjena brata Henrik in Hillebrandt, lastnika utrdbe nad Lano v dolini Adiže na južnem Tirolskem, leta 1190 pa se kot priča v neki drugi listini iz istega samostana poleg njiju omenja tudi njun oče Brandhoch, starec iz Lane (senex Brandhoch de Loeinan). ${ }^{7}$ Utrdba v Lani je 1236 prvič označena kot castrum de Brandicio in od tedaj je vsakokratni lastnik uporabljal priimek de Brandicio. ${ }^{8}$ Že v srednjem veku se omenjajo tri linije (praveje), katerih sorodstvena povezava ni povsem razjasnjena; tirolska $\mathrm{z}$ matičnim gradom Brandis nad Lano (sl. 1), ${ }^{9}$ svicarska z gradom Brandis v Burgdorfu v dolini Emme (Emmental), ki je izumrla leta $1512,{ }^{10}$ in saška, katere grad je bil v Grimmi blizu Leipziga. ${ }^{11}$ Tirolski liniji je 31. marca 1606 nadvojvoda Maksimiljan III. podelil baronski naslov, leta 1641 pa je cesar Ferdinand III. na zboru deželnih stanov (Reichstag) v Regensburgu Andreja Viljema in Vida Bena barona Brandis povzdignil v grofa (grofovsko diplomo so pridobili šele 16. februarja 1654). ${ }^{12}$ Predstavniki tirolske linije so se poleg uspešnega gospodarjenja odlikovali zlasti kot nosilci različnih visokih upravnih in političnih funkcij, iz rodbine Brandis je namreč izviralo kar sedem tirolskih deželnih glavarjev (več kot iz katere koli druge tirolske rodbine), dva tirolska guvernerja, ${ }^{13}$ Klemen grof Brandis je bil vrhovni dvorni mojster (Obersthofmeister) cesarja Ferdinanda I., imeli so častni naslov vrhovnega dednega sreberničnika na Tirolskem (Oberste Erbland Silberkämmerer in Tyrol). ${ }^{14}$ Grofje Brandis so še danes znani po svoji pobožnosti in pripadnosti Katoliški cerkvi, saj v vsej rodbini ni bilo nobenega odpada v protestantizem, skozi stoletja so dali nekaj cerkvenih dostojanstvenikov, več

5 Tina KOŠAK, Slikarska zbirka v dvorcu Betnava, Dvorec Betnava (ur. Franci Lazarini, Miha Preinfalk), Ljubljana 2018 (Castellologica Slovenica, 1), str. 289-321.

6 Simona KOSTANJŠEK BRGLEZ, Slike Leopolda Kupelwieserja v Slivnici pri Mariboru, Umetnostna kronika, 55, 2017, str. 3-12.

7 BRANDIS 1889 (op. 1), str. 1, 3, 22.

8 BRANDIS 1889 (op. 1), str. 23. O tem, da se priimek de Brandicio ne nanaša na posest, temveč gre za rodbinsko ime, gl. BRANDIS 1889 (op. 1), str. 5-7.

9 BRANDIS 1889 (op. 1), str. 3. Grad Brandis nad Lano je od leta 1807 opuščen, njegove ruševine pa so še danes v lasti rodbine. Za osnovne zgodovinske podatke o gradu gl. Josef WEINGARTEN, Die Kunstdenkmäler Südtirols, 2, Innsbruck-Wien-München-Bozen 1973, str. 247-248.

10 BRANDIS 1889 (op. 1), str. 3, 7-8. Brandis 1860 (op. 3), str. 17, navaja letnico 1509.

11 BRANDIS 1889 (op. 1), str. 3, 8-9.

12 BRANDIS 1889 (op. 1), str. 18-19, 117 (z napačno navedbo letnice 1642), 126; Karl Friedrich von FRANK, Standeserhebungen und Gnadenakte für das Deutsche Reich und die Österreichischen Erblande bis 1806 sowie kaiserlich österreichische bis 1823 mit einigen Nachträgen zum „Alt-Österreichischen Adels-Lexikon"1823-1918, 1, Schloss Senftenegg 1967, str. 120.

13 HIRN 1892 (op. 3), str. 6.

14 HIRN 1892 (op. 3), str. 8. 
1. Grad Brandis, Lana, zunanjščina

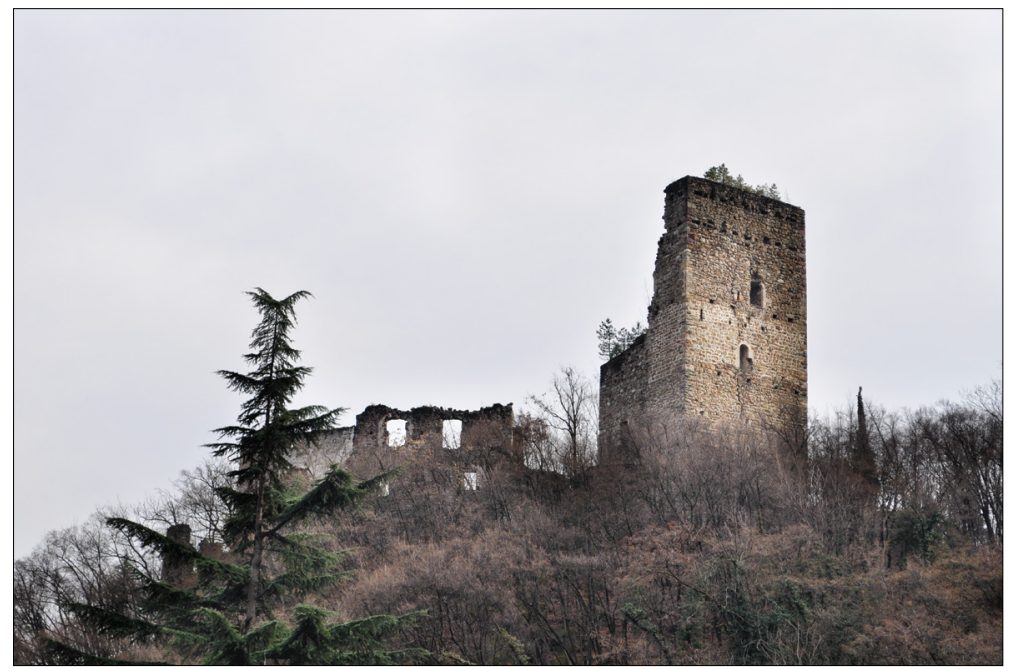

duhovnikov in redovnic in na najrazličnejše načine, tudi finančno, podpirali delovanje Cerkve. ${ }^{15}$ Nekateri predstavniki rodbine pa so imeli tudi omembe vredno vojaško kariero. ${ }^{16}$

V sedemnajstem stoletju se je s prvima grofoma Brandis, polbratoma Andrejem Viljemom (1592-1642; sin Jakoba Andreja barona Brandis in Sibile Barbare baronice Hendl pl. Goldrain) in Vidom Benom (1606-1662; sin Jakoba Andreja in Marije Izabele baronice Lamberg) tirolska linija razdelila na dve veji. Andrej Viljem se je namreč 20. junija 1618 poročil Marijo Magdaleno baronico Khünburg (Kienburg) in se preselil v Spodnjo Avstrijo, ${ }^{17}$ kjer je 14. marca 1623 pridobil deželanstvo. ${ }^{18}$ Po Khünburgih je leta 1637 dobil v last dvorec Kottingbrunn v bližini Badna, ${ }^{19}$ preko druge žene, Eve Marije baronice Urschenbeckh, pa je postal tudi lastnik gospostva Rodaun z inkorporiranim posestvom Siebenhierten (oboje je danes del Dunaja). ${ }^{20}$ Obe poroki in pridobitev omenjenih posestev predstavljajo začetek starejše ali avstrijske veje rodbine Brandis, medtem ko je Vid Beno začetnik mlajše ali tirolske veje, ki je imela glavna posestva v dolini Adiže ${ }^{21}$ Obe veji sta ključno zaznamovali tudi umetnostno podobo Štajerske.

15 Prim. HIRN 1892 (op. 3), str. 11-12. Med redovnicami osrednje mesto zavzema Marija Jožefa Brandis (18151900), ki je kot s. Leopoldina vstopila v red usmiljenk in je zaslužna za njihov prihod iz Francije v Avstrijsko cesarstvo, ustanovila pa je tudi nekatere druge redovne skupnosti, npr. Marijine sestre Čudodelne svetinje. Za temeljno delo o njej gl. [Maria KORREN], Leben und Wirken der ehrwürdigen Mutter Maria Josefa Leopoldine Brandis Gründerin und erste Visitatorin der Barmherzigen Schwester, 1-2, Graz 1915. Prim. Božidara GOLIČNIK, Mati Leopoldina Brandis. Duhovna podoba, Dobrova pri Ljubljani 1981.

16 Za najpomembnejše nosilce vojaških funkcij gl. HIRN 1892 (op. 3), str. 10.

17 BRANDIS 1889 (op. 1), str. 123. Za točen datum poroke gl. StLA, Lazarini, Familie, K. 7, H. 162, Brandis, rodovnik rodbine Brandis.

18 BRANDIS 1889 (op. 1), str. 124.

19 BRANDIS 1889 (op. 1), str. 124. Prim. Niederösterreich südlich der Donau, 1 (ur. Peter Aichinger-Rosenberger idr.), Wien 2003 (Dehio-Handbuch. Die Kunstdenkmäler Österreichs), str. 1102.

20 BRANDIS 1889 (op. 1), str. 124. Siebenhirten je bil z gospostvom Rodaun združen od leta 1559. Več o obeh posestvih in dvorcu Rodaun: Wien. X. bis XIX. und XXI. bis XXIII. Bezirk, Wien 1996 (Dehio-Handbuch. Die Kunstdenkmäler Österreichs), str. 684-685, 702-705.

21 Prim. BRANDIS 1889 (op. 1), str. 114. 


\section{Prihod grofov Brandis na Štajersko}

Po Andreju Viljemu je gospostvi Rodaun in Siebenhierten podedoval njegov sin iz drugega zakona Adam Viljem (1636-1699). ${ }^{22}$ Slednji se je leta 1670 (poročno pismo je datirano 10. aprila) poročil z Ano Marijo grofico Khisl (1643-1703), s čimer so se Brandisi sorodstveno povezali s to pomembno kranjsko in štajersko plemiško rodbino. ${ }^{23}$ Ko je umrl brat Ane Marije, zadnji grof Zwickl-Khisl, Janez Jakob (1645-1689), je več štajerskih gospostev obsegajočo Khislovo posest podedovala njegova hči Marija Eleonora, poročena grofica Orsini-Rosenberg (1676-1725). Ker s soprogom Leopoldom Jožefom (1670-1737) nista imela otrok, slednji ni bil upravičen do dediščine rodbine Khisl, zato sta po Mariji Eleonori posest dedovala njena nečaka, otroka Adama Viljema grofa Brandis, Franc Jakob (1677-1746) in Katarina, poročena grofica Drašković (u. 1751). Med novima lastnikoma je kmalu prišlo do različnih pogledov na gospodarjenje s precej zadolženo posestjo, saj se je Katarina zavzemala za prodajo gospostva Maribor, osrednjega dela dediščine, medtem ko je Franc Jakob temu nasprotoval. Zato je Franc Jakob leta 1733 prodal vso svojo spodnjeavstrijsko posest Filipu vitezu Rödersthal in njegovi soprogi Eleonori in s tem pridobil sredstva za izplačilo sestre, kar mu je uspelo 1737. S tem je postal lastnik gospostev Maribor, Gornji Maribor, Betnava z inkorporiranim Gromperkom ter Miklavž na Dravskem polju. ${ }^{24}$

Franc Jakob, ki je 10. januarja 1738 postal deželan Štajerske, ${ }^{25}$ je opravljal različne funkcije na Dunaju (mdr. komornik (Kammerherr) nadvojvode Karla (1699), kasneje v službi pri cesarju Leopoldu I., 1704 pravi spodnjeavstrijski vladni svetnik, od 1716 višji komisar pri spodnjeavstrijskih deželnih stanovih, 1722 svetnik, 1727 odbornik), ${ }^{26}$ zato se na Štajerskem kot umetnostni naročnik, vsaj kolikor je znano, ni udejstvoval. Razpetost med Spodnjo Avstrijo in Štajersko pa se kaže tudi v določilu njegove oporoke, $\mathrm{v}$ katerem je kot mesto svojega poslednjega počitka pragmatično določil bodisi nekdanjo Khislovo grobnico v kapucinski cerkvi v Mariboru bodisi Brandisovo grobnico v kapucinski cerkvi v spodnjeavstrijskem Mödlingu, odvisno od kraja smrti. Na koncu so ga pokopali v slednji. ${ }^{27}$

22 BRANDIS 1889 (op. 1), str. 139. Gospostvo Kottingbrunn je dedoval Janez Jakob (1620-1658), sin Andreja Viljema iz prvega zakona. Ta stranska veja je z Janezom Jakobom tudi izumrla, saj je njegov sin Janez Ernest umrl pred njim; prim. BRANDIS 1889 (op. 1), str. 139. Posestvo je Marija Suzana, hči Janeza Jakoba, leta 1661 prodala Francu baronu Lambergu. Gl. Joachim KÜNZEL, Kottingbrunn. Von Einst ins Jetzt, Kottingbrunn 2010, str. 17.

23 BRANDIS 1889 (op. 1), str. 140. WITTING 1919-1921 (op. 1), stp. 285, kot datum poroke navaja 29. 4. 1670. O rodbini Khisl gl. Barbara ŽABOTA, Rodbina Khisl. Novoveška zgodba o uspehu, Kronika. Časopis za slovensko krajevno zgodovino, 51/1, 2003, str. 1-26; Matjaž GRAHORNIK, Betnava v obdobju od začetka 17. do konca prve četrtine 18. stoletja, Dvorec Betnava 2018 (op. 5), str. 118-143, 146 (rodovnik).

24 BRANDIS 1889 (op. 1), str. 13, 163-165. Prim. GRAHORNIK 2018 (op. 23), str. 143. BRANDIS 1889 (op. 1), str. 163, napačno navaja, da so Brandisi po Khislih podedovali tudi gospostvo Hainfeld $\mathrm{z}$ inkorporiranim posestvom Fahrngraben v bližini Feldbacha, kar pa ne drži, saj sta ti vzhodnoštajerski posesti zakonca Orsini-Rosenberg že leta 1719 prodala Karlu grofu Purgstallu; prim. Franz PICHLER, Die Urbare, urbarialen Aufzeichnungen und Grundbücher der Steiermark, 1, Graz 1967, str. 496. Franc Jakob je bil po Mariji Eleonori grofici Orsini-Rosenberg tudi dedič posestev Črnci in Eibisfeld (Eybesfeld) blizu Lipnice, ki jih je ta podedovala po Mariji Elizabeti grofici Trauttmansdorff, roj. grofici Khisl (ok. 1640-1694), a ju je kmalu prepustil vdovcu Marije Eleonore, Leopoldu Jožefu grofu Orsini-Rosenbergu; gl. BRANDIS 1889 (op. 1), str. 163-164.

25 BRANDIS 1889 (op. 1), str. 20.

26 BRANDIS 1889 (op. 1), str. 160-161.

27 BRANDIS 1889 (op. 1), str. 166. Grobnice ni več, saj je bila kapucinska cerkev v Mödlingu podrta po razpustitvi samostana v času cesarja Jožefa II. (prim. Niederösterreich südlich der Donau, 2, Wien 2003 (Dehio-Handbuch. Die Kunstdenkmäler Österreichs), str. 1467), medtem ko nekdanja Khislova grobnica, v kateri so pokopani tudi 


\section{Henrik Adam grof Brandis - eden vodilnih baročnih naročnikov na Štajerskem}

Kot umetnostni naročnik je bil precej bolj dejaven Henrik Adam (1715-1790), edini sin Franca Jakoba in Marije Ane grofice Starhemberg, ki je preživel očeta. ${ }^{28}$ Sprva je bil v vojaški službi, 1734 kot zastavnik v pehotnem regimentu Maksa grofa Starhemberga, 1738 je v Regensburgu prevzel stotnijo svojega pri Cornei padlega brata Jakoba Andreja. Leta 1739 je na očetovo željo izstopil iz vojske, naslednjega leta je kot del cesarskega odposlanstva potoval v Carigrad, 1742 pa je postal član štajerskih deželnih stanov. ${ }^{29}$ Dve leti kasneje (poročno pismo nosi datum 4. oktober 1744) se je poročil z Marijo Ano grofico Trauttmansdorff (1712-1786), potomko stare štajerske plemiške rodbine. ${ }^{30}$ Po očetovi smrti (1746) je podedoval posest avstrijske veje Brandisov in kmalu za tem prodal posestvo Miklavž na Dravskem polju, na katerem sta s soprogo prva leta po poroki živela, ter kupil hišo v Gradcu na današnji Burggasse 4, kjer je v zimskem času z družino tudi prebival, medtem ko je v poletnih mesecih za svoje bivališče izbral reprezentančni mariborski mestni grad (sl. 2, 3). ${ }^{31}$

Nedvomno je dejstvo, da je Henrik Adam za razliko od očeta večino časa bival na Štajerskem in ne na Dunaju, vplivalo tudi na njegovo večjo naročniško vnemo. Največ pozornosti je vsekakor namenil "glavnemu sedežu« avstrijske veje Brandisov, mariborskemu mestnemu gradu, ki ga je temeljito preuredil. ${ }^{32}$ Tako je med letoma 1747 in 1749 na dvorišču gradu, na mestu starejše vežne stavbe s stopniščnim stolpom, dal postaviti sedanji poznobaročni stopniščni rizalit z monumentalnim, bogato okrašenim stopniščem, ki je pripisan mariborskemu stavbnemu mojstru Jožefu Hoferju (ok. 16961762), oblikovne značilnosti pa kažejo na morebitno sodelovanje graškega arhitekta Jožefa Hueberja (1715-1787) (sl. 4)..$^{33}$ Po mnenju Jožeta Curka je sočasno z gradnjo novega stopnišča dvoriščni portal

nekateri Brandisi, še obstaja in je pod prezbiterijem mariborske frančiškanske cerkve, ki je bila konec 19. stoletja zgrajena na mestu nekdanje kapucinske cerkve (prim. Franci LAZARINI, Frančiškanska cerkev v Mariboru, Ljubljana 2013 (Umetnine v žepu, 7), str. 47-48).

28 StLA, Lazarini, Familie, K. 7, H. 162, Brandis, rodovnik rodbine Brandis; BRANDIS 1889 (op. 1), str. 166. Francu Jakobu in Mariji Ani se je sicer rodilo 10 otrok (6 sinov, 4 hčere), od katerih pa sta samo dve hčeri in Henrik Adam preživeli očeta. Večina otrok je umrla v otroštvu, Karel in Jakob Andrej pa sta padla v vojaških spopadih.

29 BRANDIS 1889 (op. 1), str. 171. O odposlanstvu v Carigrad prim. HIRN 1892 (op. 3), str. 10.

30 BRANDIS 1889 (op. 1), str. 171-172; WITTING 1919-1921 (op. 1), stp. 286.

31 BRANDIS 1889 (op. 1), str. 172. Hišo na Burggasse 4, ki je bila pred Brandisi v lasti grofov Herberstein in grofov Attems, je leta 1804 Janez Krstnik grof Brandis prodal Trauttmansdorffom, po katerih se palača še danes imenuje. O Brandisovi graški hiši gl. Die Kunstdenkmäler der Stadt Graz. Die Profanbauten des I. Bezirkes Altstadt (ur. Wiltraud Resch), Wien 1997 (Österreichische Kunsttopographie, 53), str. 46.

32 Prim. BRANDIS 1889 (op. 1), str. 173.

33 Jože CURK, Mariborski mestni grad (Stavbno-zgodovinska skica), Kronika. Časopis za slovensko krajevno zgodovino, 7/1, 1959, str. 34; Sergej VRIŠER, Mariborski grad, Ljubljana 1969 (Kulturni in naravni spomeniki Slovenije, 17), str. 8; Jože CURK, Oris 12 najpomembnejših gradbenih objektov v Mariboru I, Časopis za zgodovino in narodopisje, 59 (n. v. 24)/1, 1988, str. 124; Ivan STOPAR, Grajske stavbe v vzhodni Sloveniji. 1: Območje Maribora in Ptuja, Ljubljana 1990 (Grajske stavbe, 1), str. 80; Nace ŠUMI, Asja KREČIČ, Maribor, mestni grad, Arhitektura 18. stoletja na Slovenskem. Obdobje zrelega baroka, Arhitekturni muzej Ljubljana, Ljubljana 2007, str. 183-184; Jože CURK, Mariborski grad, Maribor 2007 (Osvetljena dediščina, 3), str. 61, 69-71. Jože Curk v navedenih prispevkih domneva, da je stara vežna stavba s stopniščnim stolpom (datirana po 1640) vključena v sedanji stopniščni rizalit. O Jožefu Hoferju gl. Jože CURK, Nekdanji jezuitski kolegij v Mariboru in njegov gradbeni mojster Janez Fuchs, Časopis za zgodovino in narodopisje, 54 (n. v. 19)/1-2, 1983, str. 120-122; Damjan PRELOVŠEK, Hofer Jožef, Enciklopedija Slovenije, 4, Ljubljana 1990, str. 38; Igor SAPAČ, Baročni arhitekti na Slovenskem, Arhitektura 2007 (op. 33), str. 242-243; Metoda KEMPERL, Korpus poznobaročne sakralne arhitekture na slovenskem Štajerskem, Ljubljana 2007 (Historia Artis), str. 50-52. Možnost Hoferjevega sodelovanja z Jožefom Hueberjem omenja Igor SAPAČ, Arhitekturnozgodovinski oris dvorca Betnava, Dvorec Betnava 2018 (op. 5), str. 253. Osnovna literatura o Jožefu Hueberju: Walter KOSCHATZKY, Leben, Werk und Stil des Barockbaumeisters Josef Hueber, Graz 1951 


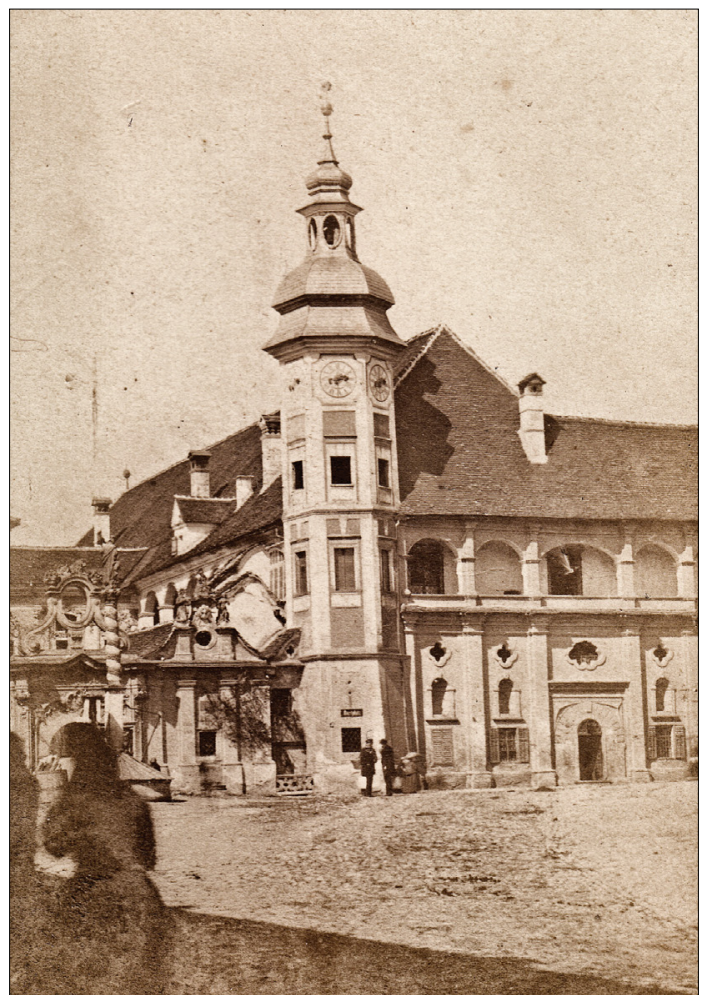

2. Ferdinand Rainer: Mestni grad Maribor, zunanjščina pred prezidavo 1871

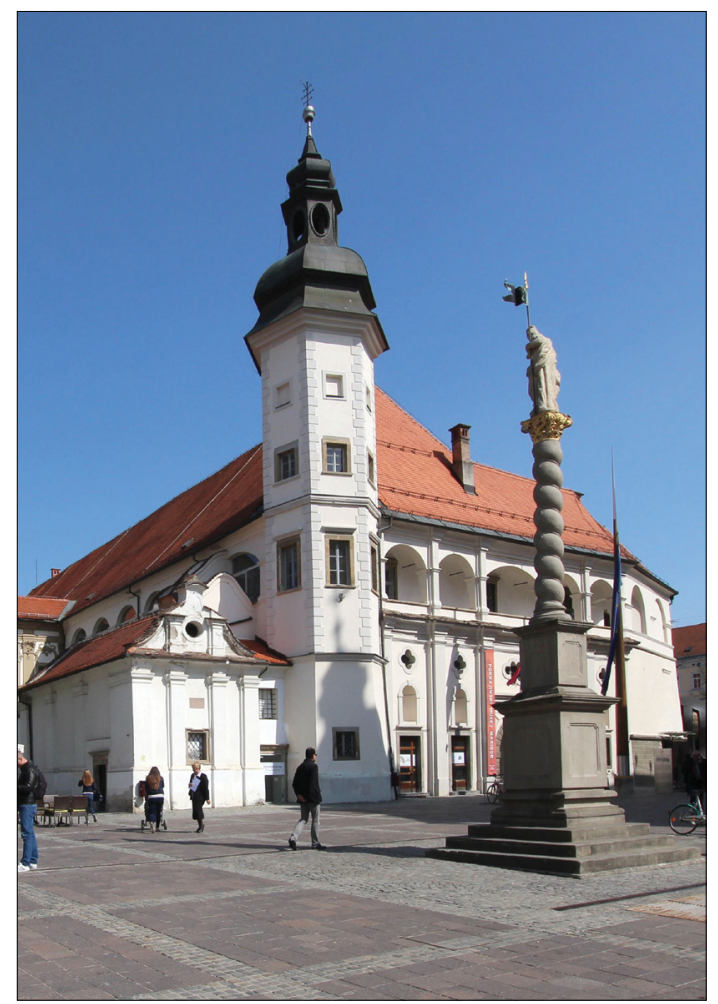

3. Mestni grad Maribor,

zunanjščina leta 2017

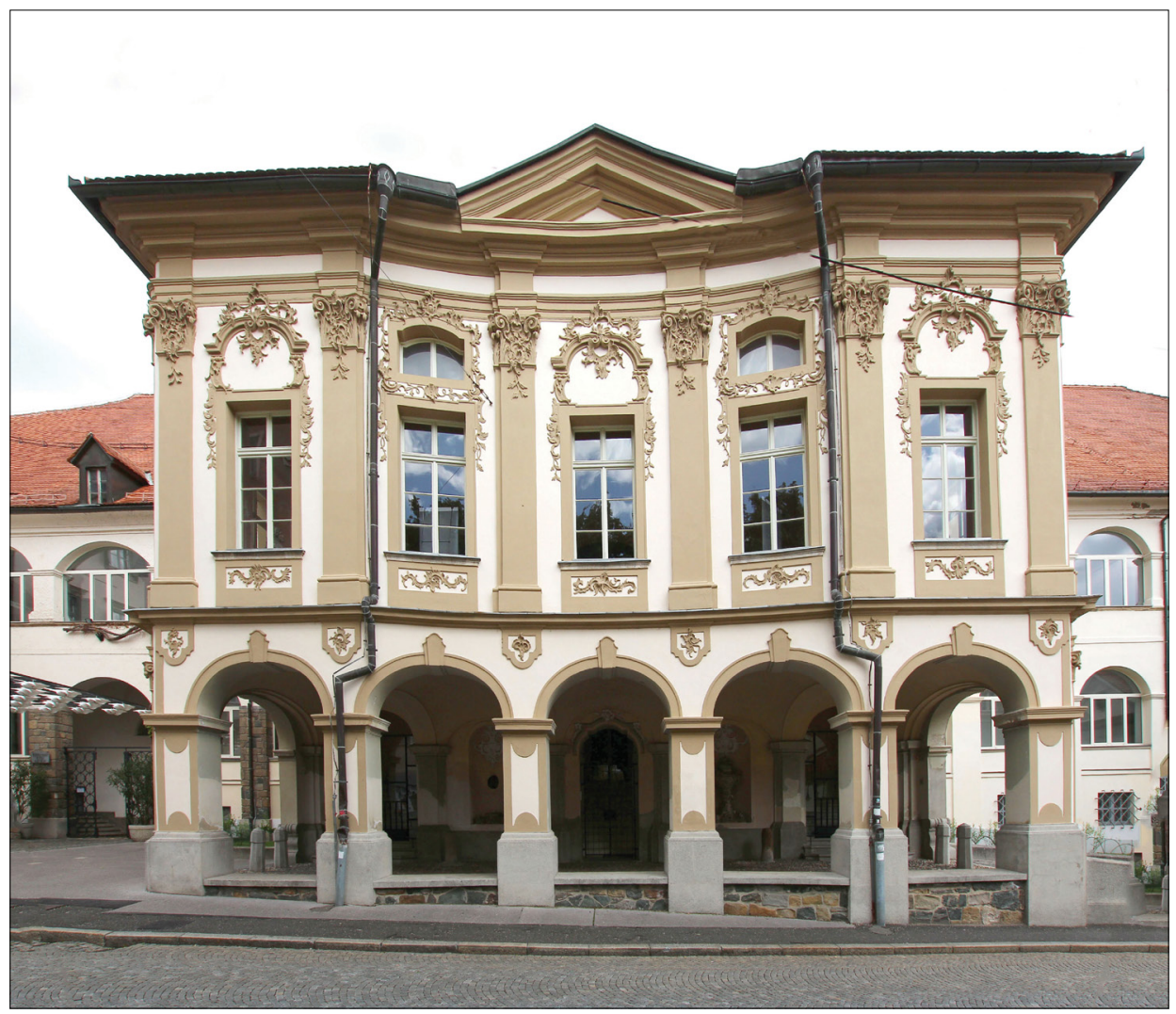

4. Jožef Hofer: Mestni grad Maribor, Stopniščni rizalit, 1747-1749 
ob loretski kapeli dobil razgiban poznobaročni zaključek. ${ }^{34} \mathrm{~V}$ petdesetih letih je sledila prezidava osrednjega dela dvorca. Leta 1751 je Henrik Adam dal nadzidati od mesta kupljeno bastijo na severovzhodnem vogalu gradu in v nadzidanem nadstropju urediti svoje stanovanje, medtem ko je osrednji del gradu od tedaj imel le še reprezentančno funkcijo. ${ }^{35} \mathrm{~V}$ istem času je prišlo tudi do manjšega gradbenega posega pri loretski kapeli, ki so jo v letih 1655-1661 dali postaviti Khisli, in sicer so na zunanjščini predelali čelo, sami kapeli pa so dozidali oratorij in ga povezali $\mathrm{z}$ arkadnim hodnikom $\mathrm{v}$ nadstropju gradu. ${ }^{36}$ Prav tako sta bila v petdesetih letih porušena severovzhodni in jugovzhodni stolp. ${ }^{37}$

Po dokončanju gradbenih del se je Henrik Adam posvetil likovni opremi osrednje dvorane. Stranska polja bogato štukiranega stropa, pripisanega štukaterju Alessandru Sereniju in njegovim pomočnikom, ${ }^{38}$ je okrog leta 1680 s prizori štirih letnih časov, Jupitra, Marsa, Sacco di Roma (?) in bitke pri Monoštru ter prizori iz Odiseje poslikal Lorenzo Lauriga, medtem ko je osrednje polje ostalo prazno. ${ }^{39}$ Leta 1763 ga je Henrik Adam dal poslikati s prizorom bitke s Turki (sl. 5). Medtem ko avtorstvo poslikave ni sporno, saj gre za signirano in datirano delo graškega slikarja Josepha Michaela Geblerja, ${ }^{40}$ pa dolgo ni bilo zadovoljivo rešeno vprašanje, katera bitka je upodobljena. Erwin Fabrici jo je interpretiral kot turško obleganje Dunaja leta $1683,{ }^{41}$ medtem ko sta Bogo Teply in Ivan Meznarič, izhajajoč iz ustne tradicije, da je upodobljena bitka povezana z družinsko zgodovino Brandisov, domnevala, da gre za bitko pri Parmi (1734), v kateri je padel naročnikov brat Karel (1710-1734). ${ }^{42}$ Šele Polona Vidmar je poudarila, da je bitka pri Parmi potekala med habsburškimi na eni in francoskimi ter sardinskimi četami na drugi strani in da v njej ni bilo Turkov. Na podlagi tega je prizor smiselno opredelila kot bitko pri Cornei (1738), v kateri je prav tako padel eden od

(tipkopis doktorske disertacije); Günther PRISCHNIG, Joseph Hueber. Spätbarocker Hofbaumeister in Graz, Graz 1994 (tipkopis doktorske disertacije); Ana LAVRIČ, Načrt graškega arhitekta Josepha Hueberja za škofovsko cerkev v Gornjem Gradu, Acta historiae artis Slovenica, 5, 2000, str. 151-166; Igor WEIGL, Dvorec Dornava in druge arhitekture Jožefa Hueberja na slovenskem Štajerskem, Dvorec Dornava. Vrišerjev zbornik (ur. Marjeta Ciglenečki), Ljubljana 2003, str. 15-62; SAPAČ 2007 (op. 33), str. 245-246; KEMPERL 2007 (op. 33), str. 63.

34 CURK 1959 (op. 33), str. 34; VRIŠER 1969 (op. 33), str. 8; CURK 1988 (op. 33), str. 124; STOPAR 1990 (op. 33), str. 80 . V obeh slednjih besedilih je navedeno, da je bil portal v celoti na novo zgrajen.

35 CURK 1959 (op. 33), str. 34; CURK 1988 (op. 33), str. 124; STOPAR 1990 (op. 33), str. 80. Bastija je bila zgrajena med letoma 1556 in $1562 \mathrm{v}$ sklopu utrjevanja mesta (prim. CURK 1959 (op. 33), str. 32).

36 Prim. CURK 1988 (op. 33), str. 124. CURK 1959 (op. 33), str. 34, sicer domneva, da je ohranjeno fasadno čelo še prvotno, a se v kasnejših besedilih tej tezi odreče.

37 CURK 1988 (op. 33), str. 124; CURK 2007 (op. 33), str. 61-62.

38 Barbara JAKI MOZETIČ, Vtis obilja. Štukatura 17. stoletja v Sloveniji, Ljubljana 1995, str. 68-69.

39 O poslikavi gl. Barbara MUROVEC, Stropna dekoracija v dvorani mariborskega gradu. Štirje letni časi Gérarda de Lairessa, Susanne Marije von Sandrart in Lorenza Laurige, Acta historiae artis Slovenica, 2, 1997, str. 53-66.

40 MUROVEC 1997 (op. 39), str. 53.

41 Erwin FABRICI, Die Burgen der Stadt Marburg a. D. mit besonderer Berücksichtingung des Treppenrisalites an der jetzigen Burg, München 1935, str. 9.

42 Bogo TEPLY, Ivan MEZNARIČ, Odprava hišne gobe ter obnova viteške dvorane v mariborskem gradu, Varstvo spomenikov, 3, 1950, str. 141-142. Kot (domnevno) bitka pri Parmi je opredeljen tudi v: CURK 1959 (op. 33), str. 34 (z napačno letnico bitke, 1743); CURK 1988 (op. 33), str. 124 (ista napaka); STOPAR 1990 (op. 33), str. 80. VRIŠER 1969 (op. 33), str. 13-14, je fresko opredelil kot »prizor konjeniškega spopada med vojskama oklepnikov in Turkov« in dodal, da je »bržkone zasnovan po fantaziji«. Temu mnenju se pridružuje tudi CURK 2007 (op. 33), str. 61, 67, ki sicer kot povod za poslikavo navaja obletnico bitke pri Parmi. 


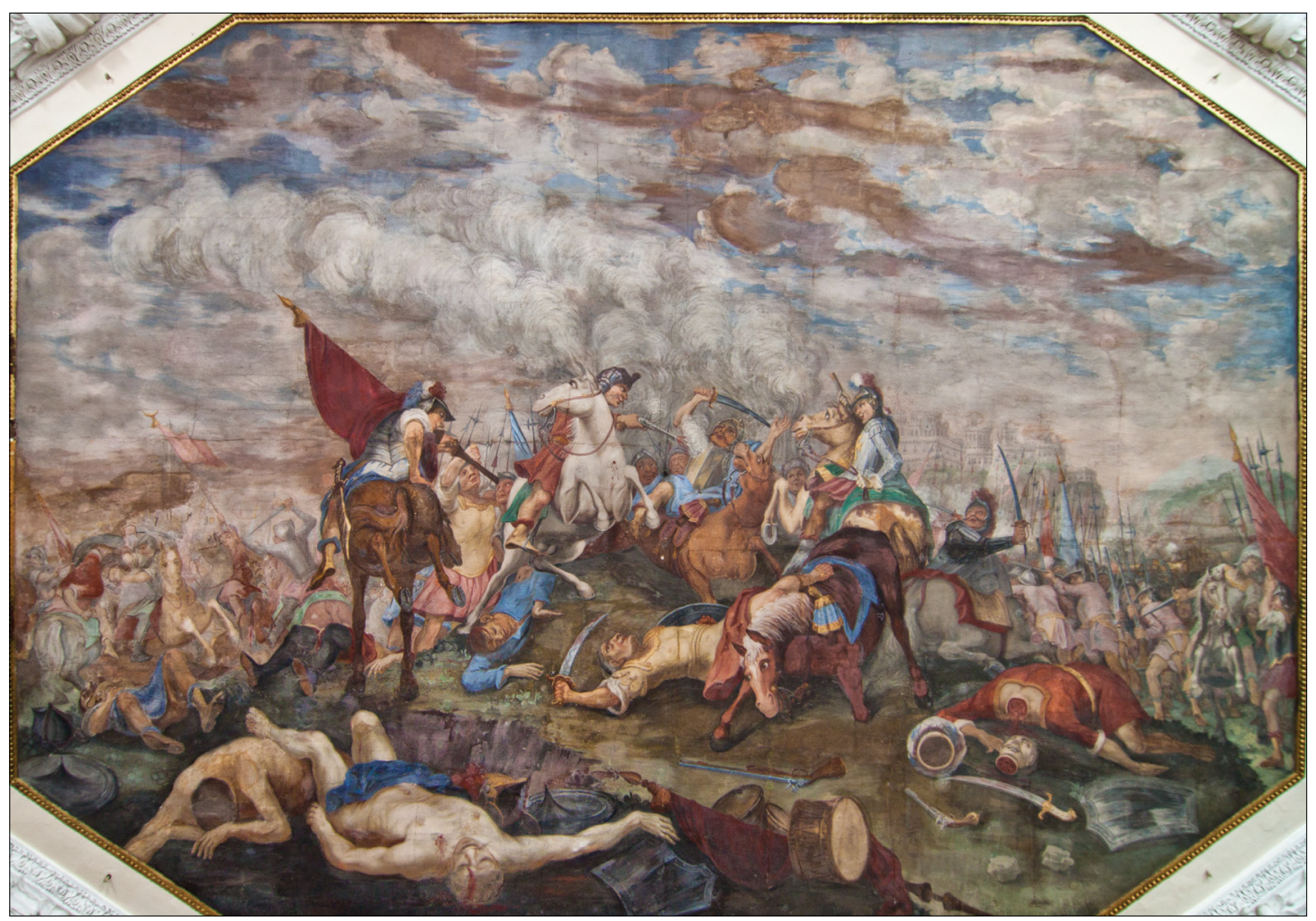

5. Joseph Michael Gebler: Bitka pri Cornei, poslikava v osrednji dvorani, Mestni grad Maribor, 1763

naročnikovih bratov, ${ }^{43}$ vendar pa ne gre za Gvidobalda Jožefa, saj je ta umrl kot otrok, temveč za Jakoba Andreja (1707-1738). ${ }^{44}$

S Henrikom Adamom je mariborski mestni grad dobil baročni videz in hkrati tudi svoj največji obseg. ${ }^{45} \mathrm{~V}$ tem reprezentančnem sedežu avstrijske veje Brandisov je Henrik Adam gostil mnogo eminentnih gostov, med katerimi brez dvoma zaseda osrednje mesto papež Pij VI., ki se je 18. marca 1782 na svoji poti na Dunaj, kjer se je pri cesarju Jožefu II. neuspešno zavzemal za omilitev njegovih cerkvenih reform, ustavil tudi v Mariboru in prenočil pri grofu Brandisu. ${ }^{46}$

43 Polona VIDMAR, De virtute heroica. Ceiling Paintings with Ottoman Struggles in Slovenia, Annales. Series historia et sociologia, 25/4, 2015, str. 806-807.

44 BRANDIS 1889 (op. 1), str. 166, 171. WITTING 1919-1921 (op. 1), stp. 286, napačno navaja, da je pri Cornei padel Gvidobald Jožef, Jakob Andrej pa umrl kot otrok. Dokumenti iz Brandisovega rodbinskega arhiva potrjujejo navedbe v Familienbuch. Gl. Archiv Brandis, Fach 141, Haubt: Abrechnung Herrn Haubtmann Jacob Grafen von Brandis.

45 CURK 1959 (op. 33), str. 33, v čas grofov Brandis postavlja tudi obnovo in prezidavo štirih vogalnih stolpov, ki jo datira z letnico 1717. Datacijo kasneje spremeni v 1727 (CURK 2007 (op. 33), str. 61) oziroma navaja le, da je bil poseg izveden v času Brandisov (CURK 1988 (op. 33), str. 124). Po Curku ta pripis prevzemata VRIŠER 1969 (op. 33), str. 8, in STOPAR 1990 (op. 33), str. 80. Vendar pa za prezidavo bržkone niso zaslužni Brandisi, saj 1717 grad še ni bil v njihovi lasti, 1727 pa je bila usoda precej zadolžene posesti zaradi različnih stališč solastnikov Franca Jakoba in Katarine nejasna, zato se ne zdi verjetno, da bi se v takšni situaciji lotili tako obsežnega posega. Poleg tega je 1727 Franc Jakob postal odbornik (Verordneter) spodnjeavstrijskih deželnih stanov in je večino časa prebival na Dunaju (prim. BRANDIS 1889 (op. 1), str. 161). CURK 1988 (op. 33), str. 124, v čas Brandisov postavlja tudi povezavo osrednje dvorane in vhodne lože z arkadnim mostovžem ter nekaj drugih gradbenih posegov (prim. CURK 2007 (op. 33), str. 61), vendar je tudi tu vprašljivo, če ni do prezidav prišlo že v času prejšnjih lastnikov.

46 O papeževem obisku gl. BRANDIS 1889 (op. 1), str. 174-175. 


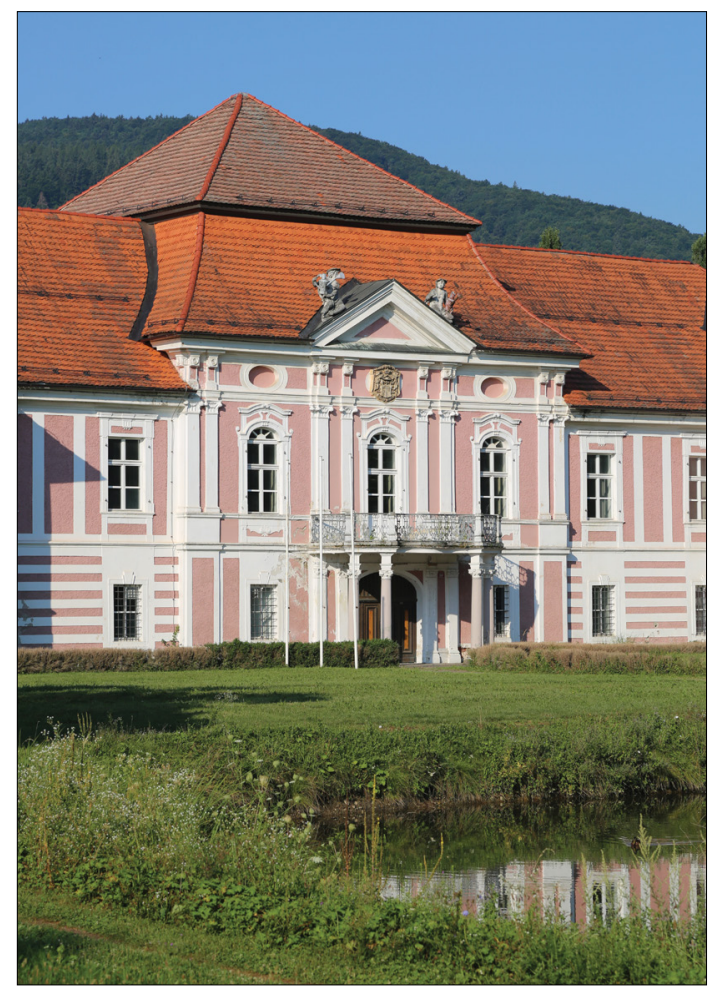

6. Jožef Hofer, Janez Nepomuk Fuchs: dvorec Betnava, prezidava ok. 1756-1781, zunanjščina

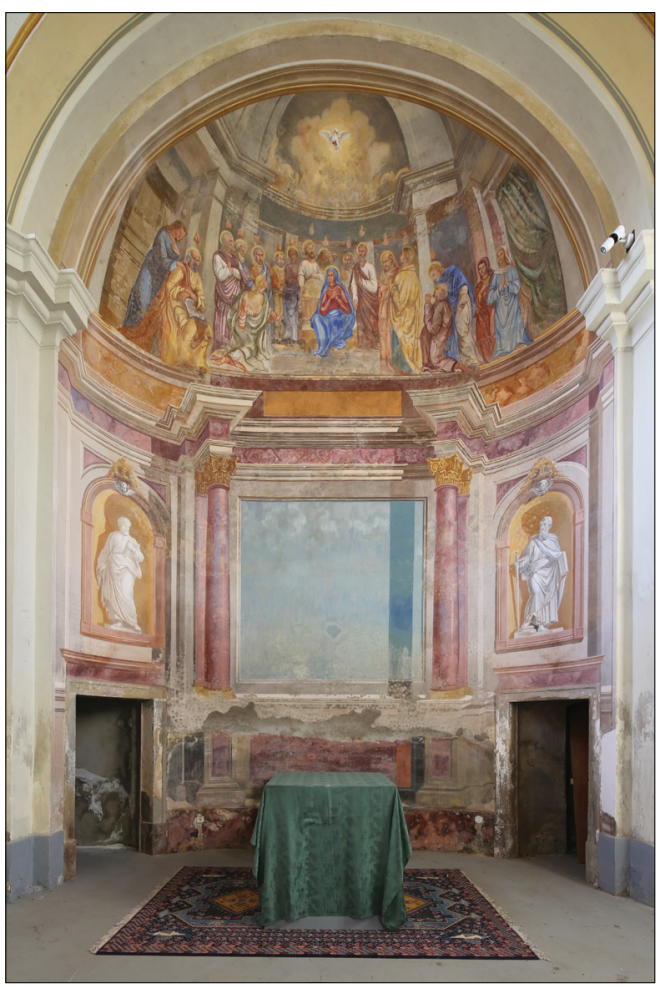

7. Dvorec Betnava, kapela sv. Križa, ok. 1772-1781, notranjščina

Drugačno usodo pa je doživel grad Gornji Maribor, ki je nekdaj stal na griču nad mestom. ${ }^{47}$ Od leta 1727 je bil opuščen in je propadal, v njem je menda bival le še pastir. ${ }^{48}$ Henrik Adam je sklenil grad, ki so ga postopoma podirali skozi več desetletij, leta 1784 dokončno odstraniti, na njegovo mesto pa postaviti klasicistično piramido, po kateri se grič še danes imenuje. ${ }^{49}$ Piramida je predstavljala pomembno mestno dominanto, nenazadnje zaradi svoje višine, ki je bila enaka višini zvonika cerkve sv. Barbare na Kalvariji. ${ }^{50}$ Napis na piramidi, ki ga je v svoji rodbinski zgodovini objavil Ferdinand grof Brandis, nam sporoča, da so kamenje porušenega gradu uporabili pri gradnji

47 O gradu Gornji Maribor gl. Jože CURK, Grad Gornji Maribor, Časopis za zgodovino in narodopisje, 58 (n. v. 23)/2, 1987, str. 241-251; Jože CURK, Grad Gornji Maribor in njegovo kulturnozgodovinsko sporočilo, Časopis za zgodovino in narodopisje, 60 (n. v. 25)/1, 1989, str. 99-108; STOPAR 1990 (op. 33), str. 75-76; Jože CURK, Grad Gornji Maribor in njegovo gradbenozgodovinsko sporočilo, Časopis za zgodovino in narodopisje, 63 (n. v. 28)/1, 1992, str. 182-187; Mira STRMČNIK GULIČ, Gornji Maribor v luči arheoloških raziskovanj, Časopis za zgodovino in narodopisje, 63 (n. v. 28)/1, 1992, str. 200-231; Mateja RAVNIK, Korenine mesta Maribor. Nova dognanja na Piramidi, Maribor 2012; Tone RAVNIKAR, Grad Gornji Maribor v srednjem veku. Odnos med plemstvom in mestom na območju Maribora, Piramida. Grič, na katerem se je začela pisati zgodovina Maribora (ur. Primož Premzl), Maribor 2014, str. 9-17; Mateja RAVNIK, Marchburch - Grad Gornji Maribor. Pregled arheoloških raziskav, Piramida 2014 (op. 47), str. 41-57.

48 BRANDIS 1889 (op. 1), str. 173; Primož PREMZL, Piramida - Grajski grič na vedutah, Piramida 2014 (op. 47), str. 28.

49 CURK 1987 (op. 47), str. 246; CURK 1992 (op. 47), str. 184. V obeh besedilih je napačna domneva, da je bil grad v celoti odstranjen 1784. Za novejša dognanja o postopnem podiranju gl. SAPAČ 2018 (op. 33), str. 236.

50 Izgled piramide je viden na dveh vedutah Maribora s konca 18. stoletja, Ludwiga Ig. v. Tiefentala (1795) in Friedricha Ferdinanda Runka (ok. 1798). Gl. PREMZL 2014 (op. 48), str. 30. 
nekaterih stavb, tako »hiše Božje« (žal ne navaja, katere), kakor tudi dvorca Betnava. ${ }^{51}$

Prav poznobaročna predelava dvorca Betnava pa je drugi pomemben spomenik, za katerega je zaslužen Henrik Adam (sl. 6). Tako je po letu 1756 dvorec izgubil svoj utrdbeni videz in dobil v precejšnji meri še danes vidno poznobaročno podobo, in to skoraj brez rušenja starejših zidanih delov, temveč le s smiselnim dopolnjevanjem obstoječe celote. ${ }^{52} \mathrm{~V}$ sklopu barokizacije so na zahodni strani severozahodnega stolpa, na mestu zasutega obrambnega jarka, dozidali še novo grajsko kapelo Svetega Križa, katere gradnjo lahko vsaj približno umestimo v obdobje 1772-1781 (sl. 7). Kapelo je do konca druge svetovne vojne kronal strešni stolpič, ${ }^{53} \mathrm{~s}$ čimer je severni trakt dvorca, ki so ga prav tako nadzidali, dobil pomemben arhitekturni poudarek. V sklopu obsežne baročne prezidave je dvorec dobil tudi osrednjo, iluzionistično poslikano dvorano ter reprezentančno stopnišče (dokončano do 1766), poudariti pa je treba, da ambiciozni baročni gradbeni poseg nikoli ni bil izveden do konca. ${ }^{54}$

Medtem ko lahko datacijo baročne predelave vsaj približno opredelimo na podlagi (delno) ohranjenih letnic 1756, 1766, 1772 in 1781, pa ostaja odprto vprašanje arhitekta prenove. Igor Sapač je na podlagi slogovne analize prišel do zaključka, da sta barokizacijo načrtovala in vodila že omenjeni Jožef Hofer in njegov naslednik Janez Nepomuk Fuchs (1727-1804), vodilna mariborska stavbna mojstra poznega baroka, pri čemer je Hofer pri pripravi koncepta baročne prezidave podobno kot pri stopniščnem rizalitu mariborskega mestnega gradu morda sodeloval z Jožefom Hueberjem. ${ }^{55}$

Henrik Adam ni dolgo užival v prenovljenih, reprezentančnih baročnih dvorcih, saj ga je marca 1787, na obisku pri sestri Juditi na Dunaju, zadela kap, zaradi katere je ostal priklenjen na posteljo, izgubil pa je tudi dar govora. ${ }^{56}$ Tri leta kasneje je v Gradcu umrl, pokopan pa je v tamkajšnji cerkvi sv. Andreja (do jožefinskih reform dominikanska cerkev). ${ }^{57}$

Od njegovih devetih otrok jih je kar osem umrlo v otroštvu, med njimi oba sinova Janez Nepomuk (1749-1759) in Alojz Adam (roj. 1755, umrl kmalu po rojstvu). Preživela je edino hči Antonija Marija (1752-1810), ki pa je bila duševno prizadeta, zato je bila v oskrbi v samostanu Säben blizu Klausna na južnem Tirolskem. ${ }^{58}$ Tako je s Henrikom Adamom izumrla starejša ali avstrijska veja grofov Brandis. Zavedajoč se tega dejstva, je Henrik Adam, še preden je zbolel, posinovil svo-

51 Za prepis napisa gl. BRANDIS 1889 (op. 1), str. 173-174; PREMZL 2014 (op. 48), str. 29. CURK 1987 (op. 47), str. 250, trdi, da so poleg dvorca Betnava iz materiala porušenega gradu zgradili tudi tri viničarije in škarpe pri bližnjih vinogradih, a ne navaja vira za svoje trditve. Večina drugih avtorjev (npr. STOPAR 1990 (op. 33), str. 75) pavšalno navaja zgolj, da so iz kamenja zgradili dvorec Betnava, le SAPAČ 2018 (op. 33), str. 236-237, meni, da so material poleg Betnave uporabljali tudi za druge stavbe. Kot so pokazale sondažne preiskave, je dvorec Betnava pretežno zgrajen iz nove opeke, zato Sapač domneva, da so gradbeni material iz Gornjega Maribora uporabili le za temelje in morda za prekrivanje strehe.

52 SAPAČ 2018 (op. 33), str. 239.

53 O kapeli gl. SAPAČ 2018 (op. 33), str. 239-241.

54 Natančneje o barokizaciji Betnave: SAPAČ 2018 (op. 33), str. 239-252. Prim. Nace ŠUMI, Asja KREČIČ, Betnava pri Mariboru, dvorec, Arhitektura 2007 (op. 33), str. 193-194.

55 O dataciji in avtorstvu barokizacije gl. SAPAČ 2018 (op. 33), str. 236, 252-254. O Janezu Nepomuku Fuchsu gl. CURK 1983 (op. 33), str. 115-119; Jože CURK, Fuchs Johann Nepomuk, Enciklopedija Slovenije, 3, Ljubljana 1989, str. 159-160; SAPAČ 2007 (op. 33), str. 237-238; KEMPERL 2007 (op. 33), str. 52-56.

56 BRANDIS 1889 (op. 1), str. 175.

57 O zadnjih letih Henrika Adama gl. BRANDIS 1889 (op. 1), str. 175-177.

58 ZAL, SI ZAL LJU/0340, Zbirka plemiških genealogij Ludvika Lazarinija, šk. 5, Brandis, 61; BRANDIS 1889 (op. 1), str. 172. 
jega sorodnika iz mlajše ali tirolske veje, Janeza Krstnika, prapravnuka začetnika veje Vida Bena. ${ }^{59}$ Tirolska veja je pridobila štajerska posestva v času, ki je bil za ambicioznejša arhitekturna in umetniška naročila manj ugoden, a je kljub temu v štajerski umetnostni dediščini 19. stoletja pustila pomemben pečat.

\section{Umetnostno naročništvo tirolske veje na Štajerskem}

Janez Krstnik grof Brandis (1751-1812) je bil gojenec dunajskega Terezijanuma, počitnice pa je običajno preživljal pri »stricu« v Mariboru. ${ }^{60}$ Ker je Henrik Adam določil v oporoki, da mora njegov dedič živeti na Štajerskem, ${ }^{61}$ se je pred "stričevo" smrtjo preselil v Gradec, ${ }^{62}$ prav tako pa se je na njegovo željo 17. aprila 1786 poročil z Marijo Jožefo grofico Trauttmansdorff (1760-1826), nečakinjo soproge Henrika Adama, Marije Ane. ${ }^{63}$ Po smrti Henrika Adama leta 1790 je podedoval posest avstrijske veje Brandisov, medtem ko sta si lastništvo posestev na Tirolskem delila s starejšim bratom Jožefom (1741-1814) ${ }^{64}$ Štajerska posest se je kmalu nekoliko zmanjšala, saj je Janez Krstnik 1804 prodal družinsko hišo v Gradcu, ${ }^{65}$ si je pa okoli 1810 prizadeval za nakup gospostva Frajštajn (Spodnja Polskava), a je finančni patent iz leta 1811 zmanjšal vrednost denarja, zaradi česar do nakupa ni prišlo. ${ }^{66}$ Janez Krstnik, ki je bil nosilec različnih političnih in upravnih funkcij (mdr. 1776-1781 pravi vladni in komorni svetnik pri spodnjeavstrijski vladi v Freiburgu, 1782-1787 vrhovni dvorni mojster princese Kunigunde Saške, od 1783 cesarsko-kraljevi tajni svetnik, 1801 nadomeščal deželnega glavarja Kranjske in Koroške, 1802-1805 guverner Tirolske), ${ }^{67}$ je živel v ekonomsko in politično zelo nestabilnih časih vojn z Napoleonom, ${ }^{68} \mathrm{ki}$ niso bili ugodni za umetnostna naročila. Edini znani gradbeni poseg je odstranitev severozahodnega stolpa in čela južne fasade mariborskega mestnega gradu, do česar je prišlo pred letom $1795 .{ }^{69}$ Za razliko od prednikov Janez Krstnik tudi ni zapustil oporoke, tako da se je po njegovi smrti, 1 . maja $1812,{ }^{70}$ lastnina razdelila med tri njegove preživele otroke (od sedmih),

59 BRANDIS 1889 (op. 1), str. 175.

60 BRANDIS 1889 (op. 1), str. 175, 198.

61 BRANDIS 1889 (op. 1), str. 204.

62 BRANDIS 1889 (op. 1), str. 200-201. Tirolski veji so deželanstvo na Štajerskem podelili 13. julija 1790 (BRANDIS 1889 (op. 1), str. 20, 218).

63 ZAL, SI ZAL LJU/0340, Zbirka plemiških genealogij Ludvika Lazarinija, šk. 5, Brandis, 75; šk. 8, Trauttmansdorff, 64; BRANDIS 1889 (op. 1), str. 175, 200, 230.

64 BRANDIS 1889 (op. 1), str. 204. Leta 1814 sta Jožefova vdova Frančiška in hčerka Marija Ana njegovo polovico za 15.400 goldinarjev prodali sinu Janeza Krstnika, Henriku Adamu. Polovico kupljenih posesti je Henrik Adam 1821 prodal svojemu mlajšemu bratu Klemenu, drugo (tj. svojo) polovico pa v petdesetih letih 19. stoletja svojemu nečaku Antonu Adrijanu; prim. BRANDIS 1889 (op. 1), str. 221, 228, 229, 235.

65 BRANDIS 1889 (op. 1), str. 210.

66 BRANDIS 1889 (op. 1), str. 218. Frajštajn je želel nameniti mlajšemu sinu Klemenu, medtem ko bi starejši Henrik Adam podedoval obstoječo Brandisovo posest.

67 Funkcije naštete v: BRANDIS 1889 (op. 1), str. 198-199, 205-206; HIRN 1892 (op. 3), str. 8.

68 BRANDIS 1889 (op. 1), str. 214-215. Med drugim je 1805 kot tirolski guverner moral Tirolsko predati Napoleonovi zaveznici Bavarski; prim. HIRN 1892 (op. 3), str. 8.

69 CURK 1988 (op. 33), str. 124; CURK 2007 (op. 33), str. 62.

70 BRANDIS 1889 (op. 1), str. 218. Pokopan je na pokopališču St. Marx na Dunaju. 
sinova Henrika Adama in Klemena ter hčerko Kunigundo. Štajerska posestva sta si med seboj razdelila oba brata, in sicer tako, da je starejši Henrik Adam dobil gospostvi Maribor in Gornji Maribor, mlajši Klemen pa Betnavo z Gromperkom, medtem ko sta tirolska posestva vse do Klemenove smrti upravljala skupaj. ${ }^{71}$ Oba brata sta izjemno pomembna tudi $\mathrm{z}$ vidika umetnostnega naročništva.

Henrik Adam (1787-1869), ime je dobil po svojem uglednem botru, je mladost preživel v Gradcu, Celovcu, Innsbrucku in Mariboru, šolal se je v Gradcu in po končanem študiju stopil v uradniško službo. Sprva je bil avskultant (sodniški pripravnik) pri Štajerski deželni pravdi (Landrecht) v Gradcu, nato je delal pri Spodnjeavstrijski deželni pravdi na Dunaju in od 1812 zopet pri deželni pravdi v Gradcu. ${ }^{72}$ Istega leta je po očetu podedoval gospostvi Maribor in Gornji Maribor, hkrati je do polnoletnosti prevzel skrbništvo za mladoletna brata Klemena in sestro Kunigundo. ${ }^{73}$ Dne 19. septembra 1814 se je v Gradcu poročil z Marijo Jožefo grofico Welsersheimb (1791-1869), s katero

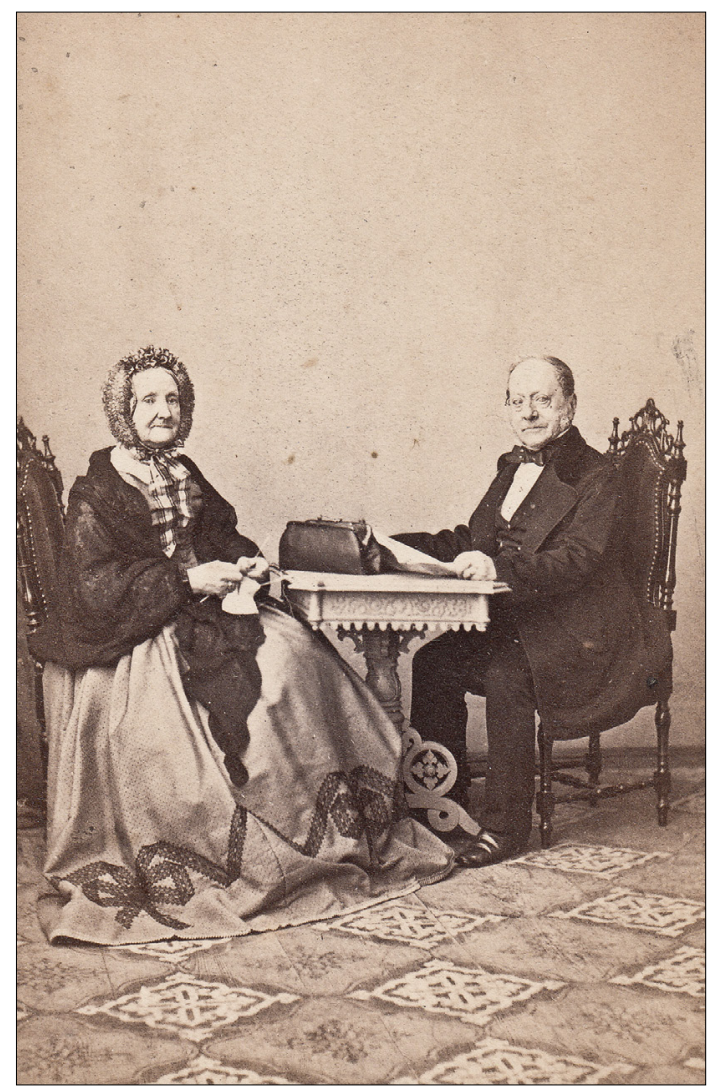

8. Henrik Adam grof Brandis (1787-1869) s soprogo Marijo Jožefo, grofico Welsersheimb sta imela šest otrok (sl. 8). ${ }^{74}$ Istega leta je postal tajnik Štajerske deželne pravde (überzäh-

liger Landrechts-Sekretär), 1822 pa ga je cesar Franc I. imenoval za spodnjeavstrijskega deželnega svetnika, zaradi česar se je z družino preselil na Dunaj. ${ }^{75}$ Bivanje na Dunaju je bilo med drugim pomembno tudi za Henrikovo (in Klemenovo) umetnostno naročništvo, saj se je tam razen z različnimi cerkvenimi dostojanstveniki (predvsem iz vrst redemptoristov, npr. generalnim vikarjem redemptoristov v Avstrijskem cesarstvu, p. Jožefom Amandom Passeratom) precej družil s slikarjem Leopoldom Kupelwieserjem, s katerim so Brandisi v kasnejših desetletjih veliko sodelovali. ${ }^{76}$ V cesarski prestolnici je družina ostala do 1831, ko so se, predvsem na soprogino željo, vrnili v Maribor, pri čemer je Henrik Adam obdržal naziv spodnjeavstrijskega deželnega svetnika. ${ }^{77}$ Od

71 BRANDIS 1889 (op. 1), str. 219, 227. Kunigunda grofica Brandis (1804-1843) je bila poročena s Ferdinandom grofom Orsini-Rosenbergom, živela pa je v Celovcu. Prim. ZAL, SI ZAL LJU/0340, Zbirka plemiških genealogij Ludvika Lazarinija, šk. 5, Brandis, 99, 116.

72 BRANDIS 1889 (op. 1), str. 227.

73 BRANDIS 1889 (op. 1), str. 227.

74 ZAL, SI ZAL LJU/0340, Zbirka plemiških genealogij Ludvika Lazarinija, šk. 5, Brandis, 99; BRANDIS 1889 (op. 1), str. 228.

75 BRANDIS 1889 (op. 1), str. 230.

76 BRANDIS 1889 (op. 1), str. 230.

77 BRANDIS 1889 (op. 1), str. 230-231. 


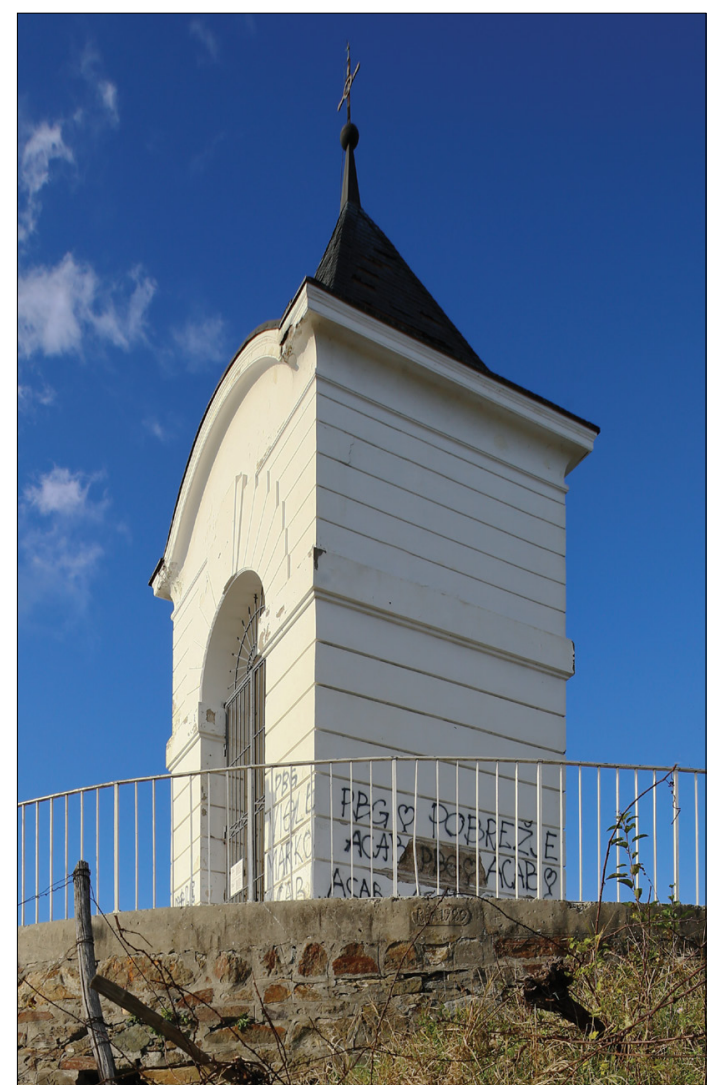

9. Kapela Brezmadežne na Piramidi, Maribor, 1821, predelana 1909, zunanjščina vrnitve z Dunaja je vse do smrti pretežno živel v Mariboru in se politično ni udejstvoval, je pa v mariborskem mestnem gradu gostil različne prominentne goste, med katerimi zaseda osrednje mesto ruski car Aleksander I., ki je v gradu bival med potjo na ljubljanski kongres Svete alianse leta 1821. Slednji je v gradu celo praznoval pravoslavni božič, za ta namen so $\mathrm{v}$ eni izmed sob začasno uredili pravoslavno kapelo. ${ }^{78} \mathrm{~V}$ času Henrika Adama se je posest Brandisov znova nekoliko povečala. Tako je že kmalu po prevzemu dediščine kupil hišo na Herrengasse v Gradcu, nasproti mestne župnijske cerkve, ${ }^{79}$ okoli 1820 pa je od matere dobil tudi posestvo Murstätten blizu Lebringa, ki ga je ta dobila 1813 v dar od Jožefe in Frančiške grofic Herberstein. ${ }^{80}$ Oboje je prodal pred selitvijo na Dunaj leta $1822 .{ }^{81}$

Tudi Henrik Adam je tako kot njegov »baročni« soimenjak posegel v podobo mariborskega mestnega gradu, vendar pa v njegovem primeru prenovi niso botrovale želje po večji reprezentativnosti, temveč so jo sprožile urbanistične zahteve naraščajočega Maribora. Ko so bila leta 1827 v sklopu odstranjevanja mestnega obzidja porušena Ulrikova (Graška) mestna vrata, je bila južna fasada gradu podaljšana za dve osi in obdana s paličastim zidcem, 1843 pa je dal Henrik Adam za potrebe kameralne okrajne uprave nadzidati upravno poslopje. ${ }^{82}$

Ko je leta 1821 udar strele popolnoma razdejal zgoraj obravnavano piramido na vrhu istoimenskega hriba, je dal Henrik Adam v duhu značilne pobožnosti rodbine Brandis na njeno mesto postaviti klasicistično kapelo Brezmadežne. Slednja je bila 1909 nekoliko predelana, spremenjena je bila oblika strehe, trikotni zatrep na fasadi je bil zamenjan s segmentnim, s čimer je kapela do neke mere izgubila svoj klasicistični značaj (sl. 9). ${ }^{83}$

78 BRANDIS 1889 (op. 1), str. 228-229.

79 BRANDIS 1889 (op. 1), str. 228. Brandisova hiša na Herrengasse je bila porušena ob širitvi ulice v osemdesetih letih 19. stoletja.

80 Josef Andreas JANISCH, Topographisch-statistisches Lexikon von Steiermark mit historischen Notizen und Anmerkungen, 2, Graz 1885, str. 334; BRANDIS 1889 (op. 1), str. 229.

81 BRANDIS 1889 (op. 1), str. 230. JANISCH 1885 (op. 80), str. 334, navaja, da je leta 1821 dvorec kupil F. Knieberger. V petdesetih letih 19. stoletja je Henrik Adam ponovno kupil Murstätten, a ga je kmalu zopet prodal. Gl. BRANDIS 1889 (op. 1), str. 235; prim. JANISCH 1885 (op. 80), str. 334.

82 CURK 1959 (op. 33), str. 34; CURK 1988 (op. 33), str. 124; CURK 2007 (op. 33), str. 62; prim. VRIŠER 1969 (op. 33), str. 9; STOPAR 1990 (op. 33), str. 80. Upravno poslopje mariborskega mestnega gradu je bilo leta 1929 temeljito prezidano v Kavarno Astoria.

83 Igor SAPAČ, Katalog pomembnejših klasicističnih, bidermajerskih in historističnih arhitekturnih stvaritev na 
Kapelo na Piramidi, ki še danes predstavlja pomembno mestno dominanto, je posvetil Karel grof Welsersheimb (1798-1880), redemptorist in kasnejši stolni župnik v Olomucu, sicer pa svak Henrika Adama. ${ }^{84}$ Prav rodbina Welsersheimb je bila tesno povezana $\mathrm{z}$ redemptoristi in tudi Henrik Adam je imel v času bivanja na Dunaju pogoste stike $\mathrm{z}$ vodilnimi predstavniki tega reda. Ko so 1831 v Avstrijsko cesarstvo prišle tudi redemptoristke, sta $\mathrm{v}$ njihov red vstopili tašča Henrika Adama, Marija Antonija grofica Welsersheimb (1772-1841), roj. grofica Suardi, in njena najmlajša hči Marija Ana (1805-1877), sam pa je kot deželni svetnik pomagal vzpostaviti prvo naselbino redemptoristk na Dunaju. ${ }^{85}$ Prav tako sta skupaj s sekovskim škofom Romanom Zängerlejem pripeljala redemptoriste tudi v Maribor, $\mathrm{v}$ katerem vse od odhoda minoritov leta $1818 \mathrm{ni}$ bilo nobenega samostana. $\mathrm{V}$ pismu, napisanem na Dunaju, 23. januarja 1829, je Brandis škofu

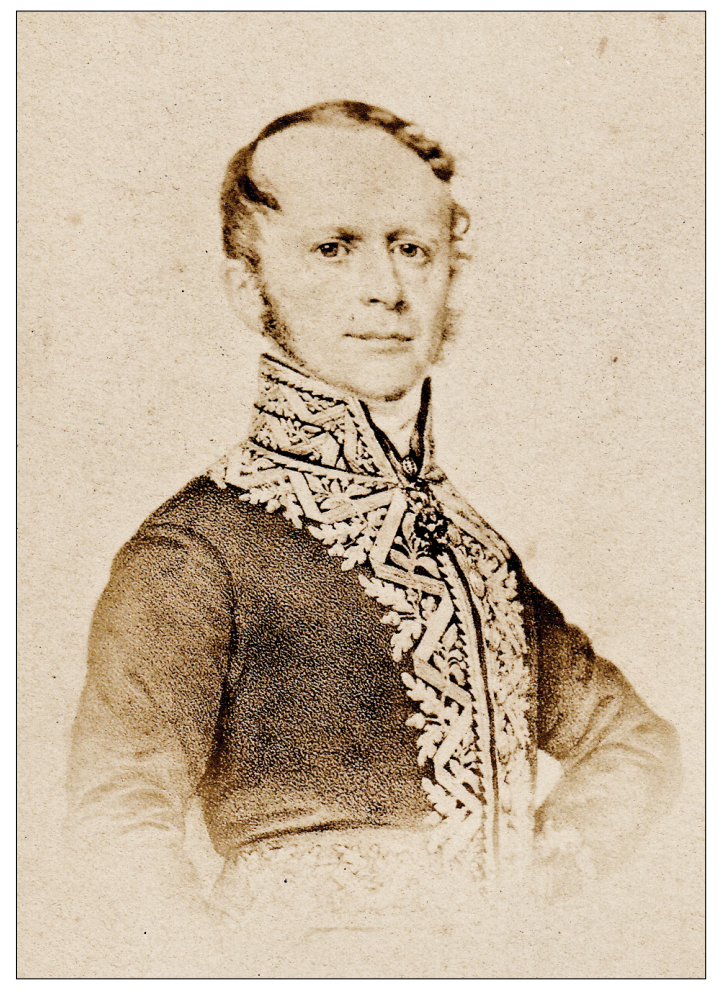

10. Klemen grof Brandis (1798-1863) Zängerleju predlagal naselitev redemptoristov v Mariboru, istega leta so redovniki zaprosili za prevzem tamkajšnje predmestne župnije, cesar Franc I. pa je njihovo naselitev odobril 1832. Na začetku naslednjega leta so redovniki prišli v Maribor in se naselili v stavbi nekdanjega kapucinskega samostana, ki ga je v letih 1613-1620 na zunanji strani Graških mestnih vrat dal postaviti Janez Jakob grof Khisl. ${ }^{86}$ Ob naselitvi so se pojavile težave s kresijo, ki jih je Henrik Adam pomagal rešiti. ${ }^{87}$ Ker je bila stara kapucinska cerkev Marije Matere usmiljenja premajhna za naraščajoče mestno prebivalstvo, obisk cerkve pa se je povečal tudi zaradi Marijine milostne podobe, ki so jo v cerkev leta 1787 prinesli minoriti in je tam ostala tudi po njihovem odhodu iz Maribora, so 1839 redemptoristi dali izdelati načrte za novo cerkev. Gradbeno dovoljenje so pridobili šele 4 . decembra 1847, vendar do gradnje, ki naj bi se pričela 1851, ni prišlo, čemur so verjetno botrovali različni razlogi, nenazadnje tudi dejstvo, da se redemptoristom v Mariboru ni uspelo uveljaviti in so že 1849, po vsega šestnajstih letih, zapustili Maribor. ${ }^{88}$ Njihov

območju Republike Slovenije, v: Igor Sapač, Franci Lazarini, Arhitektura 19. stoletja na Slovenskem, Ljubljana 2015, str. 521.

84 BRANDIS 1889 (op. 1), str. 229. Za podatke o Karlu grofu Welsersheimbu gl. ZAL, SI ZAL LJU/0340, Zbirka plemiških genealogij Ludvika Lazarinija, šk. 20, Welsersheimb, 40.

85 BRANDIS 1889 (op. 1), str. 230. Genealoški podatki povzeti po: ZAL, SI ZAL LJU/0340, Zbirka plemiških genealogij Ludvika Lazarinija, šk. 20, Welsersheimb, 40.

86 BRANDIS 1889 (op. 1), str. 231-232. O redemptoristih v Mariboru gl. Michael NAPOTNIK, Die Basilika zur Heiligen Maria, Mutter der Barmherzigkeit, in der Grazervorstadt zu Marburg, Marburg 1909, str. 11-22; prim. LAZARINI 2013 (op. 27), str. 9.

87 BRANDIS 1889 (op. 1), str. 231.

88 Otmar VOSTNER, Ob stoletnici frančiškanov v Mariboru. 1864-1964, Maribor 1964, str. 17; LAZARINI 2013 (op. 27), str. 9. 
samostan s cerkvijo so 1864 prevzeli frančiškani in na njunem mestu v letih 1893-1900 zgradili neoromansko baziliko in samostan. Edino, kar je ostalo od stare cerkve, je kripta s Khislovo grobnico, v kateri sta poslednje počivališče našla tudi Henrik Adam in Marija Jožefa, o čemer priča njun nagrobnik, sekundarno vzidan v steno hodnika okrog prezbiterija frančiškanske cerkve. ${ }^{89}$

Precej bolj razgibana od življenja Henrika Adama je bila življenjska pot njegovega mlajšega brata Klemena (1798-1863) (sl. 10), vidnega avstrijskega politika predmarčne dobe. Slednji je po končanem študiju na dunajskem Terezijanumu (1821) opravljal različne uradniške službe. Sprva je bil konceptni praktikant v različnih krajih Tirolske in Predarlske (Schwaz, Rovereto, Bregenz in Bozen/Bolzano), 1825 je postal gubernialni tajnik v Benetkah, leto kasneje pa v Ljubljani, od 1829 je bil gubernialni svetnik. V letih 1831-1835 je bil okrožni glavar v Postojni, 1835-1838 pa je opravljal isto funkcijo v Bolzanu..$^{90}$ Njegov strm vzpon se je začel ob dednem poklonu tirolskih deželnih stanov cesarju Ferdinandu I. v Innsbrucku, 12. avgusta 1838. Tedaj ga je cesar, ki je bil Klemenu kot že njegov oče Franc I. zelo naklonjen, imenoval za pravega tajnega dvornega svetnika, čemur je sledila Klemenova selitev na Dunaj, 1841 pa ga je imenoval za tirolskega guvernerja in deželnega glavarja. ${ }^{91} \mathrm{Na}$ tem položaju je zelo uspešno deloval do revolucionarnega leta 1848 , ko je moral oditi zaradi spletk na dvoru, ki se je z Dunaja začasno umaknil v Innsbruck. ${ }^{92}$ Po nekaj mesecih umika iz javnega življenja se je že konec leta vrnil »v velikem slogu«, saj ga je cesar Ferdinand I., ki je 2. decembra 1848 odstopil v korist svojega nečaka Franca Jožefa I., le šest dni po abdikaciji imenoval za svojega vrhovnega dvornega mojstra. Na tej funkciji je vodil selitev nekdanjega cesarja v Prago ter prenovo njegovih letnih rezidenc Zákupy (Reichstadt) in Ploskovice (Ploschkowitz) na Češkem. ${ }^{93}$ Zaradi intrige na dvoru je leta 1851 moral zapustiti tudi ta položaj in se od tedaj, razen funkcije člana gosposke zbornice državnega zbora, ki jo je opravljal od 1861 dalje ${ }^{94}$ ni več politično udejstvoval, še vedno pa je ostal vidna oseba v javnem življenju.

Klemen grof Brandis je bil izjemno aktiven tudi kot naročnik. Medtem ko je na Tirolskem in Češkem naročal predvsem v funkciji guvernerja oziroma vrhovnega dvornega mojstra, pa so bila njegova štajerska naročila izključno zasebne narave. ${ }^{95}$ Klemenu je namreč v času, ko je opravljal različne javne funkcije, uspelo tudi precej razširiti svojo posest. Tako je leta 1828 od Štajerskega verskega fonda kupil gospostvo Frajštajn, za nakup katerega se je neuspešno zavzemal že njegov oče, ${ }^{96}$

89 LAZARINI 2013 (op. 27), str. 48.

90 BRANDIS 1889 (op. 1), str. 238-239; Andreas M. KRAMP, Clemens Graf Brandis (1798-1863). Eine Biographie, Innsbruck 2000 (tipkopis doktorske disertacije), str. 21-51; LAZARINI 2016 (op. 4), str. 75-77. O Klemenu grofu Brandisu prim. HIRN 1892 (op. 3), str. 9; Brandis Clemens Franz Graf, Österreichisches Biographisches Lexikon 1815-1950 (ur. Leo Santifaller), 1, Graz-Köln 1957, str. 107.

91 BRANDIS 1889 (op. 1), str. 239-241; KRAMP 2000 (op. 90), str. 77-110; LAZARINI 2016 (op. 4), str. 77-78; prim. HIRN 1892 (op. 3), str. 9.

92 O Brandisu kot deželnem glavarju in guvernerju gl. BRANDIS 1889 (op. 1), str. 240-242; KRAMP 2000 (op. 90), str. 110-286. O dogodkih v revolucionarnem letu 1848 gl. BRANDIS 1889 (op. 1), str. 242-244; KRAMP 2000 (op. 90), str. 354-358.

93 BRANDIS 1889 (op. 1), str. 244-245; KRAMP 2000 (op. 90), str. 370-386, 427-431; LAZARINI 2016 (op. 4), str. 79, 83. Prim. Martin HALATA, Dvormistři císaře Ferdinanda I./V., Ferdinand V. Dobrotivý a umění jeho doby (ur. Jaroslav Sojka), Praha 2012, str. 260 (z napačno navedbo, da je Klemen funkcijo vrhovnega dvornega mojstra opravljal do svoje smrti).

94 BRANDIS 1889 (op. 1), str. 246; HIRN 1892 (op. 3), str. 9.

95 Za Klemena grofa Brandisa kot umetnostnega naročnika gl. LAZARINI 2016 (op. 4), str. 80-89.

96 Josef Andreas JANISCH, Topographisch-statistisches Lexikon von Steiermark mit historischen Notizen und Anmerkungen, 1, Graz 1878, str. 231; Ivan STOPAR, Grajske stavbe v vzhodni Sloveniji. 2: Med Prekmurjem in 
še pomembnejši pa je bil nakup gospostev Slivnica ter Ravno polje $\mathrm{z}$ inkorporiranim posestvom Šentjanž na Dravskem polju (danes Starše), do katerega je prišlo 1847. Prav nakup Slivnice je imel za Klemena velik pomen, saj si je za bivališče izbral prav ta dvorec in ne Betnave. Slednjo je proti koncu življenja sklenil celo prepustiti lavantinski škofiji. ${ }^{97} \mathrm{Na}$ Štajerskem je Klemen zaslužen za dve pomembnejši umetnostni naročili. Tako je leta 1834 , ob nenadni smrti svoje soproge Adrienne Des Enffans d'Avernas (1810-1834, poročila sta se 17. maja 1831) dal na magdalenskem pokopališču v Mariboru postaviti grobno kapelo, v kateri je bil kasneje tudi sam pokopan. Ob opustitvi magdalenskega pokopališča je bila 1891 kapela porušena, iz njenih kamnov pa je Klemenov sin Anton Adrijan dal postaviti novo grobno kapelo na pobreškem pokopališču (sl. 11). Ker nam izgled stare kapele ni poznan, ne moremo vedeti, v kolikšni meri se nova kapela zgleduje po njej, poudariti pa je tre-

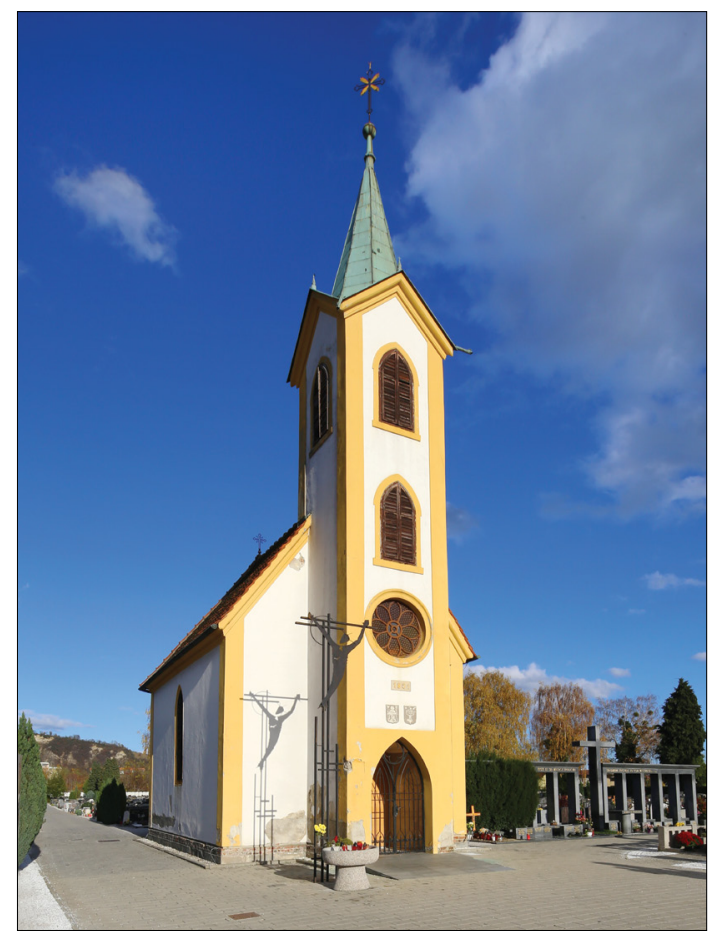

11. Grobna kapela Brandisov na pobreškem pokopališču, Maribor, 1891, zunanjščina ba, da je bila vanjo prenesena Kupelwieserjeva slika, o kateri bomo še spregovorili. ${ }^{98}$

Osrednja vloga dvorca Slivnica, ki ga je Klemen leta 1847 kupil od Karla in Jožefa knezov Poniatovski, je že bila izpostavljena, prezidava dvorca med letoma 1859 in 1863 pa je brez dvoma Klemenovo najpomembnejše naročilo na Štajerskem. Pri obsežni prezidavi, ki jo je vodil mariborski stavbni mojster Ferdinand Brodback, avtor načrtov pa ni znan, so ohranili pettraktno tlorisno zasnovo dvorca, s porušitvijo enega od stolpov, nadzidavo drugega in dozidavo monumentalne grajske kapele pa je stavbna gmota postala precej bolj razgibana. Na zunanjščini so bili dodani najrazličnejši neogotski in v manjši meri neoromanski stavbni členi, s čimer je dvorec dobil »romantični« videz (sl. 12). V notranjščini je pomembna zlasti rebrasto obokana vhodna veža z najstarejšimi primeri tudorskega loka pri nas, pri ograji monumentalnega stopnišča pa prvič na Slovenskem srečamo prefabricirane betonske elemente (sl. 13). ${ }^{99}$ Sočasno z gradbenimi posegi je bil na novo

porečjem Dravinje, Ljubljana 1991 (Grajske stavbe, 2), str. 23. Posestvo Frajštajn je bilo do cerkvenih reform cesarja Jožefa II. v lasti samostana dominikank v Studenicah, po njegovem razpustu 1782 pa je posestvo prevzel Štajerski verski fond.

97 BRANDIS 1889 (op. 1), str. 244; KRAMP 2000 (op. 90), str. 370-386; LAZARINI 2016 (op. 4), str. 85-86. Na izgled dvorcev Ravno polje in Šentjanž Brandisi niso vplivali. Za temeljni prispevek o dvorcu Ravno polje gl. Igor SAPAČ, In memoriam dvorec Ravno polje, Zbornik za umetnostno zgodovino, n. v. 38, 2002, str. 200-226.

98 Za kratek opis kapele na magdalenskem pokopališču gl. JANISCH 1885 (op. 80), str. 188. O sedanji kapeli gl. Vladimir TRAVNER, Pokopališča v Mariboru, Kronika slovenskih mest, 3/3, 1936, str. 215-217; SAPAČ 2015 (op. 83), str. 526; LAZARINI 2016 (op. 4), str. 84.

99 O prezidavi gl. Igor SAPAČ, Gradovi in dvorci, v: Sapač, Lazarini 2015 (op. 83), str. 123; SAPAČ 2015 (op. 83), str. 608; LAZARINI 2016 (op. 4), str. 86-88. 
12. Dvorec Slivnica, prezidava 1859-1863, zunanjščina

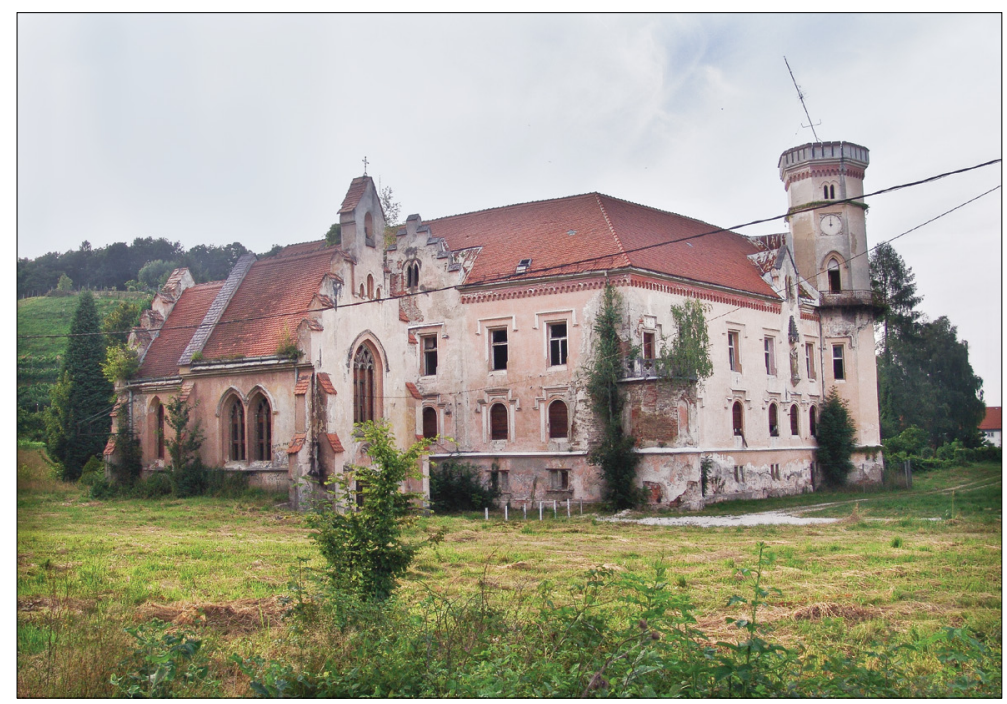

13. Dvorec Slivnica, prezidava 1859-1863, notranjščina

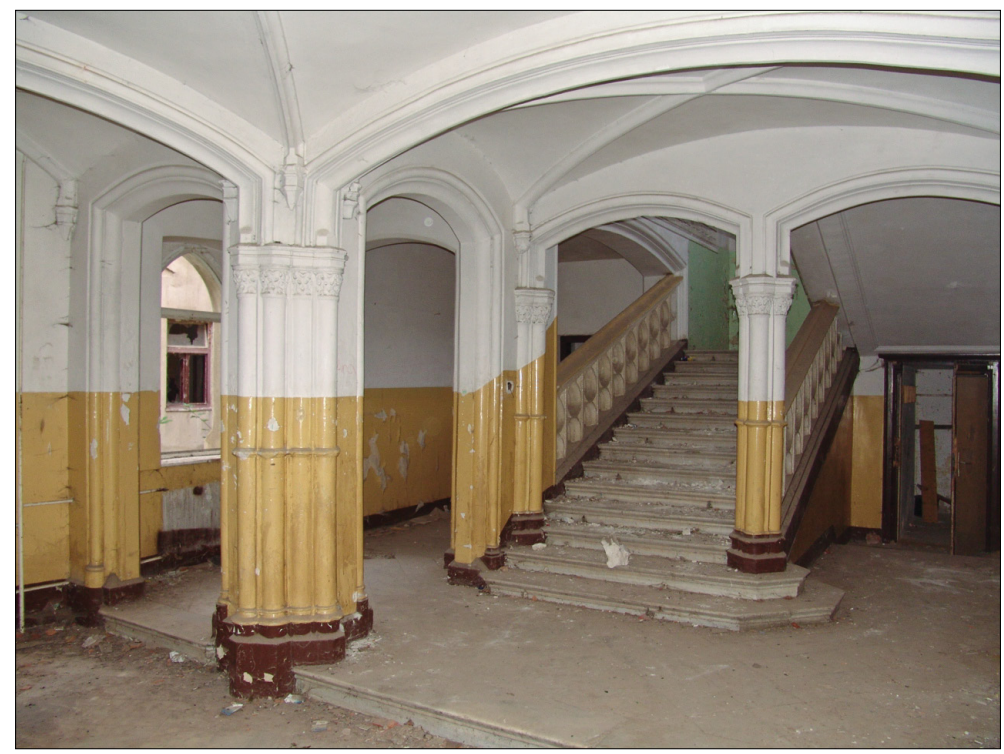

zasajen grajski park, v dvorec pa so prenesli tudi del slikarske zbirke iz dvorca Betnava. ${ }^{100}$ Zaradi velikopotezne Klemenove prezidave sodi dvorec Slivnica, skupaj z dvorcema Viltuš in Jelše (Jelšingrad), med najpomembnejše historistične dvorce na Slovenskem. ${ }^{101}$

Na tem mestu moramo posebej izpostaviti povezavo med rodbino Brandis ter slikarjem Leopoldom Kupelwieserjem (1796-1862), profesorjem na dunajski Akademiji upodabljajočih umetnosti in osrednjim predstavnikom nazarencev v Avstrijskem cesarstvu. ${ }^{102} \mathrm{Na}$ podlagi družinske zgodovine

${ }^{100}$ O historiatu betnavske slikarske zbirke gl. KOŠAK 2018 (op. 5), str. 289-321.

101 Prim. SAPAČ 2015 (op. 99), str. 123-127.

102 Temeljna literatura o Leopoldu Kupelwieserju: Eberhard HEMPEL, Kupelwieser, Leopold, Allgemeines Lexikon der Bildenden Künstler von der Antike bis zur Gegenwart, 22, Leipzig 1928, str. 121-123; Rupert FEUCHTMÜLLER, Leopold Kupelwieser und die Kunst der österreichischen Spätromantik, Wien 1970. 


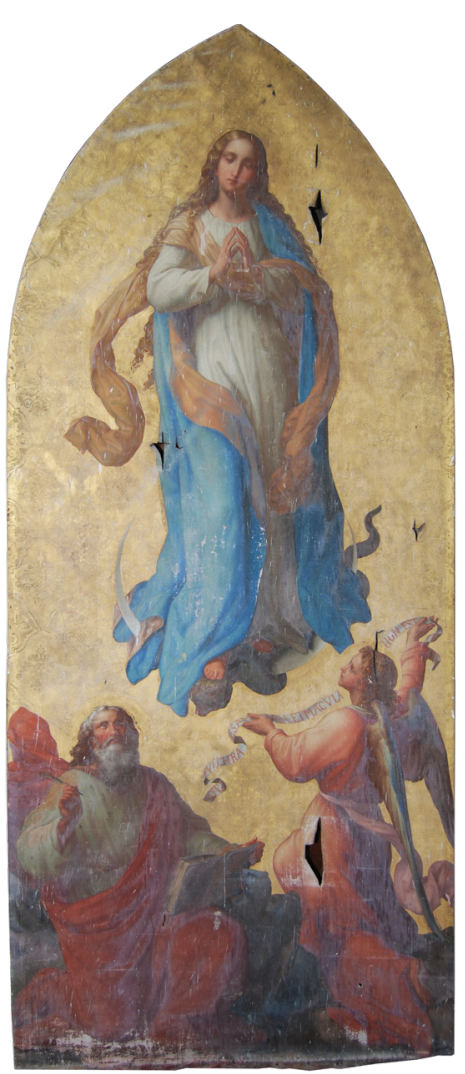

14. Leopold Kupelwieser: Brezmadežna, iz kapele dvorca Slivnica, 1862

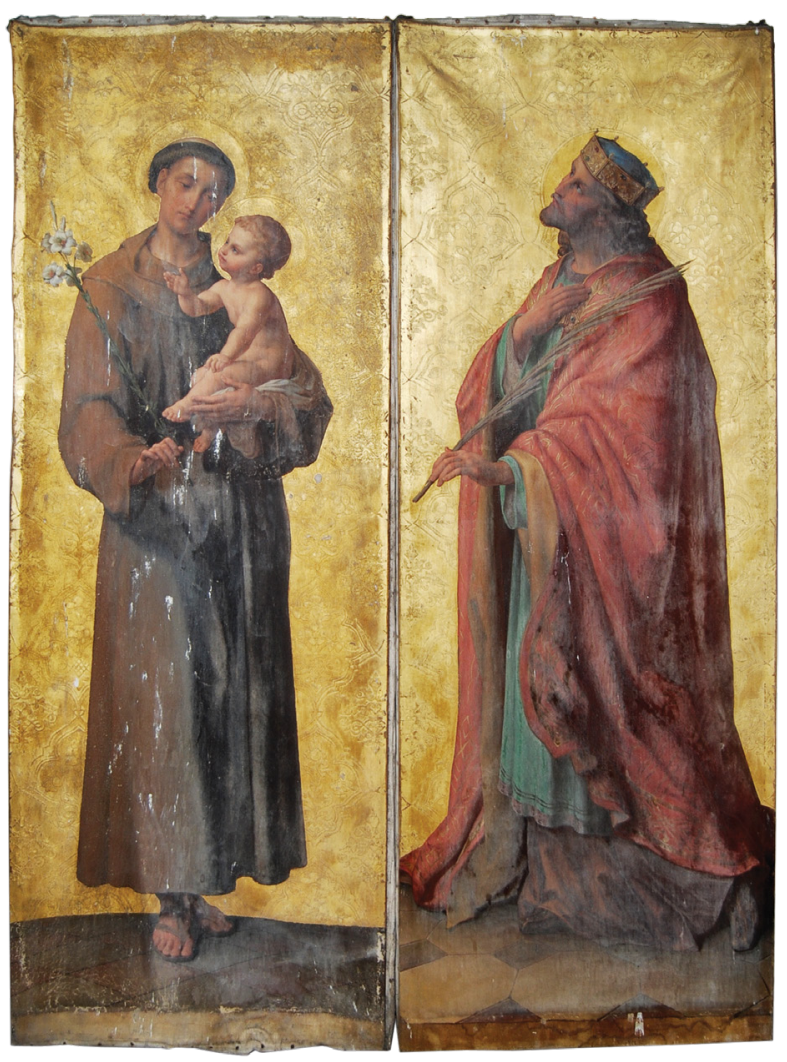

15. Leopold Kupelwieser: Sv. Anton Padovanski in sv. Erik, iz kapele dvorca Slivnica, 1862

Brandisov vemo, da je bil Henrik Adam v času svojega bivanja na Dunaju v stikih z umetnikom, ${ }^{103}$ po vsej verjetnosti preko brata pa je ob gradnji grobne kapele na magdalenskem pokopališču z umetnikom v stik stopil tudi Klemen. Tako je slikar za Brandisovo grobno kapelo na magdalenskem pokopališču naslikal oltarno sliko Marije z Detetom in sv. Klemenom ter sv. Hadrijanom (1835), zavetnikoma Klemena in njegove prezgodaj umrle soproge Adrienne. ${ }^{104}$ Skoraj tri desetletja kasneje je Klemen pri Kupelwieserju naročil tudi oltarni triptih za tedaj zgrajeno kapelo dvorca Slivnica, z upodobitvijo Brezmadežne na osrednji sliki ter zavetnikov Klemenovih sinov, sv. Antona Padovanskega in sv. Erika na stranskih (1862). ${ }^{105}$ Po drugi svetovni vojni izginule slike so bile leta 2010 najdene v zvoniku in za oltarjem župnijske cerkve Marijinega rojstva v Slivnici, sedaj pa so v tamkajšnjem župnišču (sl. 1415). ${ }^{106} S$ Kupelwieserjem je bila povezana tudi hči Henrika Adama, Ana Marija (1818-1888), poročena baronica Lazarini, ki je slikarja spoznala v času očetovega službovanja na Dunaju, z njim pa je obdržala stike tudi po poroki in selitvi v dvorec Smlednik na Kranjsko. ${ }^{107}$ Tako je Ana Marija za veliki oltar

${ }^{103}$ BRANDIS 1889 (op. 1), str. 230.

${ }^{104}$ O sliki gl. TRAVNER 1936 (op. 98), str. 215, 217; FEUCHTMÜLLER 1970 (op. 102), str. 44, 222, 258; KOSTANJŠEK BRGLEZ 2017 (op. 6), str. 11-12.

${ }^{105}$ Gl. KOSTANJŠEK BRGLEZ 2017 (op. 6), str. 8-12.

${ }^{106}$ Gl. KOSTANJŠEK BRGLEZ 2017 (op. 6), str. 3.

${ }^{107}$ Prim. Franc LAZARINI, Zgodovina rodbine Lazarini. Kronika, dokumenti, genealogija, komentarji, zgodbe, Radovljica 2013, str. 296. Po ustnem izročilu, ohranjenem pri rodbini Lazarini, je Kupelwieser v Smlednik celo 


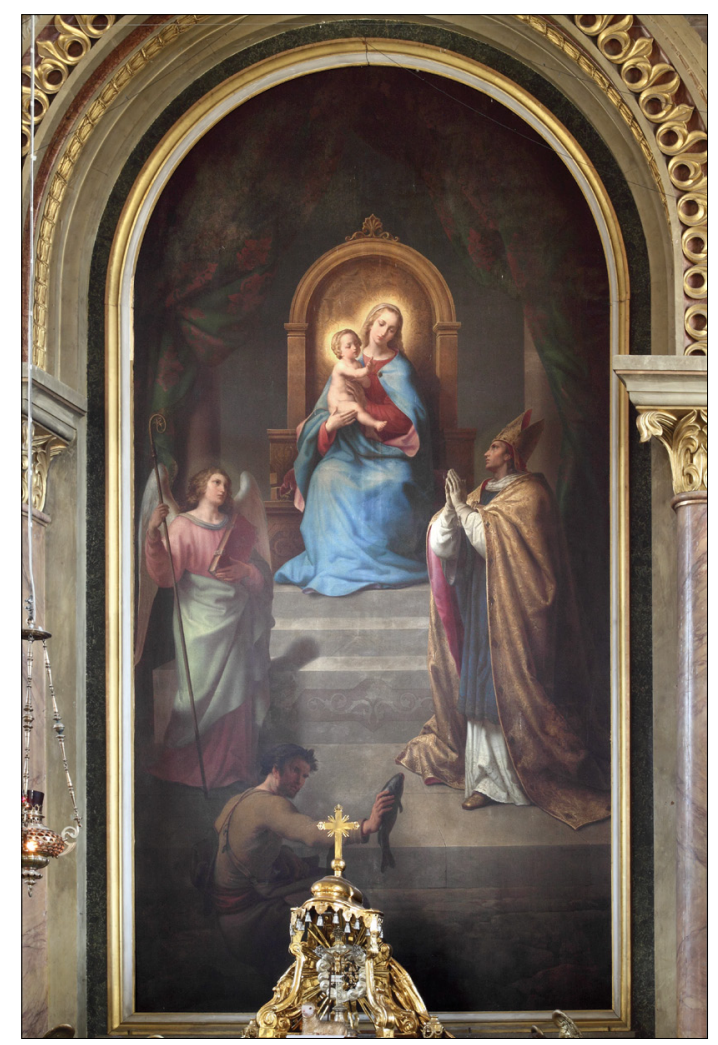

16. Leopold Kupelwieser: Čudež sv. Urha, ž.c. sv. Urha, Smlednik, 1847 novozgrajene župnijske cerkve sv. Urha v Smledniku podarila Kupelwieserjevo sliko Čudež sv. Urha (1847) (sl. 16), pri čemer je treba poudariti, da je tudi sam oltar zasnoval Kupelwieser. ${ }^{108}$ Prav tako je Ana Marija za oltar v grobni kapeli Lazarinijev na smledniškem pokopališču (18611862) pri slikarjevem učencu Leopoldu Mayerju naročila sliko Snemanje s križa (1862). ${ }^{109}$ Odprto pa ostaja vprašanje slik sv. Viktorina Ptujskega in sv. Maksimiljana Celjskega (obe 1861) na stranskih oltarjih nekdanje bogoslovne cerkve sv. Alojzija v Mariboru, ki ju je Kupelwieser naslikal skupaj s sodelavcem Josefom Kesslerjem. Njun naročnik je bil kanonik Marko Glazer, vendar pa tudi v tem primeru ne gre izključiti posredovanja katerega od Brandisov. ${ }^{110}$

Po vsej verjetnosti so preko Leopolda Kupelwieserja grofje Brandis prišli v stik še $\mathrm{z}$ enim pomembnim umetnikom sredine 19. stoletja, Karlom Rösnerjem (1804-1869), enim od osrednjih dunajskih arhitektov romantičnega historizma in Kupelwieserjevim profesorskim kolegom na akademiji, ki je zaslužen za vsaj dve arhitekturni naročili rodbine Brandis. ${ }^{11}$ Tako je Rösner po posredovanju že omenjene hčerke Henrika Adama Ane Marije in njenega soproga Franca Ksaverja Feliksa barona Lazarinija (1802-1860) izdelal načrte za župnijsko cerkev sv. Urha v Smledniku (1847-1849, posvečena 1851) prve historistične cerkve na Kranjskem in enega redkih primerov romantičnega historizma na Slovenskem (sl. 17). ${ }^{112}$ Karl Rösner pa je prav tako avtor načrtov za kapelo Brezmadežnega spočetja v Pinkafeldu na Gradiščanskem (1854-1855), ki je del tamkajšnjega samostana usmiljenk (sl. 18); slednjega je ustanovila s. Leopoldina (krstno ime Marija Jožefa) Brandis (1815-1900), prav tako hčerka Henrika Adama, sicer pa ustanoviteljica in prva vizitatorka usmiljenih sester v Avstrijskem cesarstvu. ${ }^{113}$ Precej verjetna pa se zdi tudi domneva, da je Rösner ali kdo iz njegovega kroga avtor

poslal nekega svojega učenca, da je učil Anine otroke risanja.

${ }^{108}$ Franci LAZARINI, Oprema in poslikava župnijske cerkve sv. Urha v Smledniku, Kronika. Časopis za slovensko krajevno zgodovino, 58/2, 2010, str. 420-421. Veliki oltar je po Kupelwieserjevi zasnovi izdelal podobar Matija Tomc.

109 LAZARINI 2013 (op. 107), str. 300.

${ }^{110}$ O slikah gl. Ana LAVRIČ, Mariborski sv. Alojzij Josefa Tunnerja kot zavetnik znanosti in študirajoče mladine, Umetnostna kronika, 42, 2014, str. 7-8.

${ }^{111}$ Za temeljno študijo o Karlu Rösnerju gl. Dagmar REDL, Karl Rösner. Ein Wiener Architekt von europäischem Format, Österreichische Zeitschrift für Kunst und Denkmalpflege, 52, 1998, str. 550-574.

${ }^{112}$ Franci LAZARINI, Župnijska cerkev v Smledniku in njen arhitekt Karl Rösner, Acta historiae artis Slovenica, 13, 2008, str. 109-117.

${ }^{113}$ O samostanu v Pinkafeldu gl. Burgenland (ur. Adelheid Schmeller-Kitt), Wien 1976 (Dehio-Handbuch. Die Kunstdenkmäler Österreichs), str. 235. 


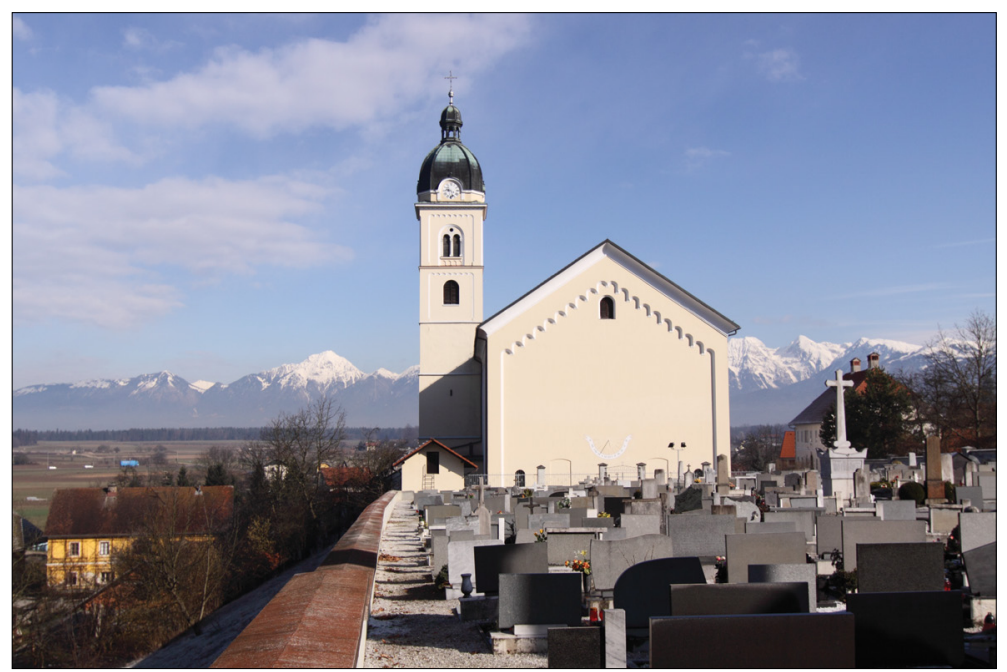

17. Karl Rösner: ž. c. sv. Urha, Smlednik, 1847-1849, zunanjščina

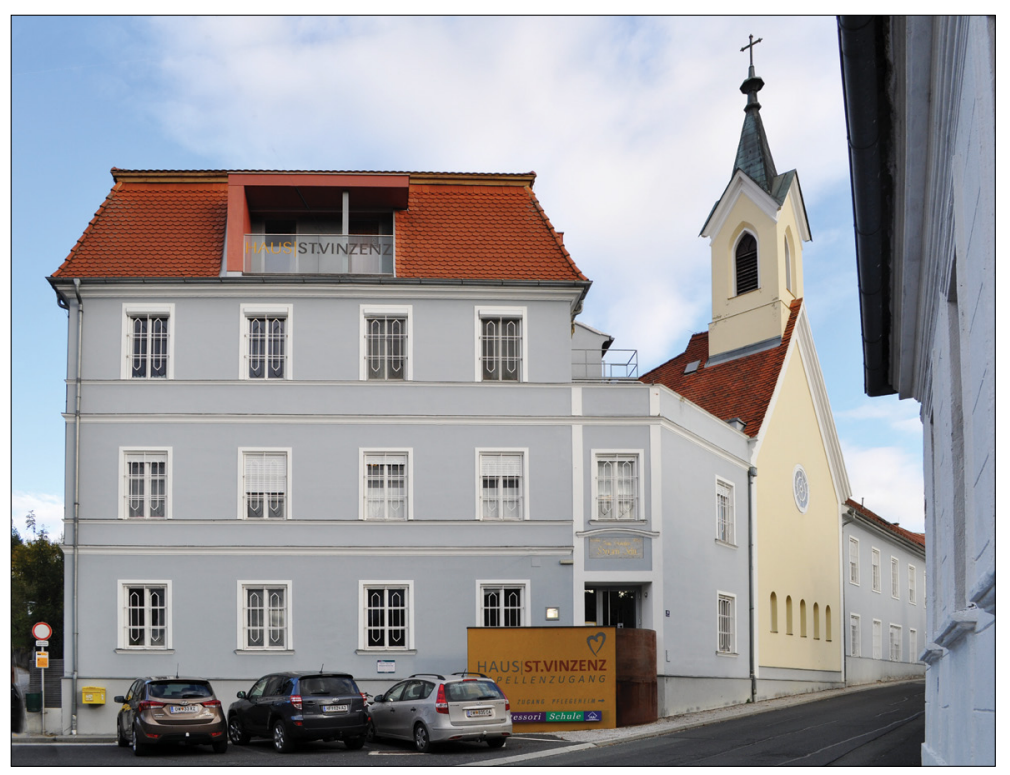

18. Karl Rösner: kapela Brezmadežnega spočetja, samostan usmiljenk $v$ Pinkafeldu, 1854-1855, zunanjščina

ambicioznega načrta za prezidavo dvorca Slivnica, saj že sama kakovost in naprednost arhitekturnih form kažeta na sposobnega arhitekta nadregionalnega formata. ${ }^{114}$

\section{$\sim$}

Z generacijo, ki je sledila naročniško izjemno dejavnima bratoma Henriku Adamu in Klemenu, se končata delovanje in bivanje rodbine Brandis na Štajerskem. Klemenov sin Anton Adrijan (18321907) (sl. 19), ${ }^{115}$ ki je podedoval celotno posestvo, saj je mlajši brat Erik (1834-1921) vstopil v jezuitski

114 SAPAČ 2015 (op. 83), str. 608; LAZARINI 2016 (op. 4), str. 87.

115 ZAL, SI ZAL LJU/0340, Zbirka plemiških genealogij Ludvika Lazarinija, šk. 5, Brandis, 102. 
red, ${ }^{116}$ je že v letu očetove smrti dokončal dogovore $\mathrm{z}$ lavantinsko škofijo in ji za potrebe letne rezidence prepustil dvorec Betnava. Precej kompleksne dogovore je z lavantinskim knezoškofom Antonom Martinom Slomškom začel že Klemen. Ker njegov mlajši sin Erik zaradi redovniškega stanu ni smel dedovati posesti, je oče v oporoki jezuitom namenil 100.000 goldinarjev za nakup redovne hiše (po možnosti na Tirolskem). Po prenosu sedeža lavantinske škofije v Maribor leta 1859 so jezuiti kupili nekdanja škofijska poslopja v Šent Andražu v Labotski dolini ter posesti na Koroškem, ki jih škofija po prenosu sedeža ni več potrebovala. Ker je škofija kupnino nameravala porabiti za nakup posesti v okolici Maribora, dolg jezuitov do nje pa je po plačanem prvem obroku prav tako znašal 100.000 goldinarjev, je Anton Adrijan 1863 sklenil dogovor s Slomškovim naslednikom Jakobom Maksimiljanom Stepišnikom, na podlagi katerega je Brandis namesto volila jezuitom prepustil lavantinski škofiji dvorec Betnava. ${ }^{117}$ Posestvo Gromperk z ruševinami istoimenskega gradu, ki je bilo prej inkorporirano Betnavi, pa je Anton obdržal in ga upravljal s Slivnice. ${ }^{118}$

Podobno kot oče je bil tudi Anton Adri-

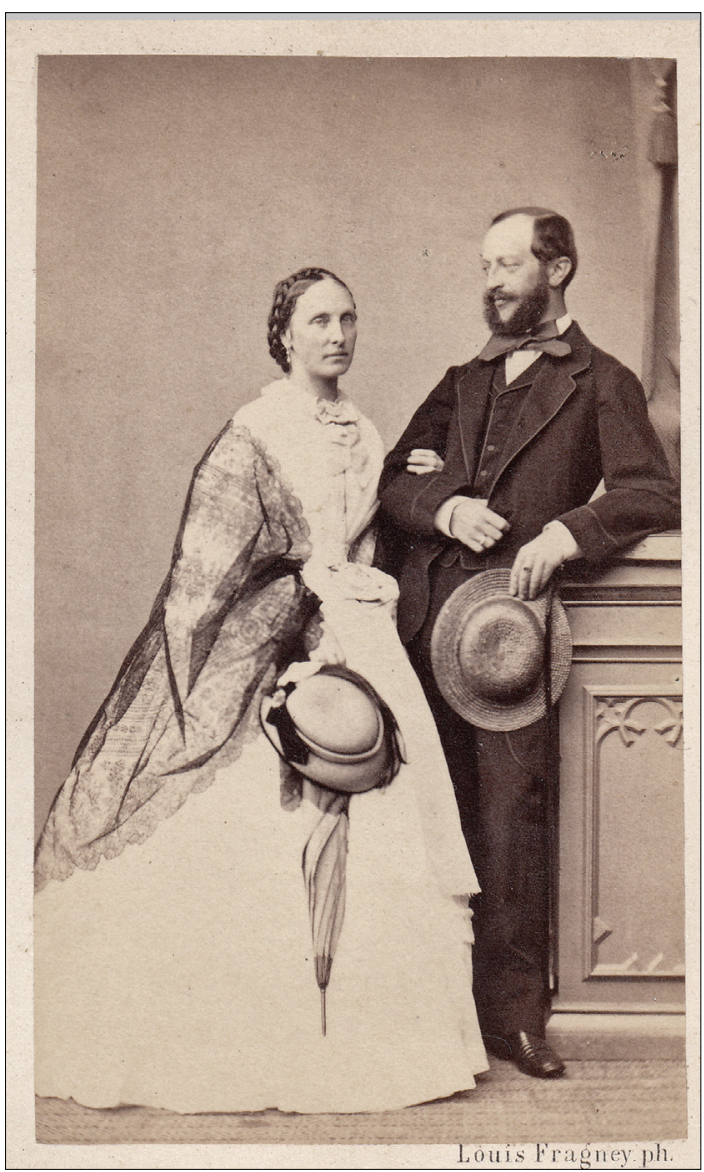

19. Anton Adrijan grof Brandis (1832-1907) s soprogo Terezijo Sofijo, baronico Gudenus jan aktiven $\mathrm{v}$ politiki, med drugim je bil $\mathrm{v}$ letih 1889-1904 tirolski deželni glavar. ${ }^{119}$ Verjetno mu zaradi oddaljenosti ni bilo v interesu imeti posestev na Štajerskem, zato je leta 1880 prodal Slivnico in ostala štajerska posestva. ${ }^{120}$ Ker s soprogo Terezijo Sofijo, roj. baronico Gudenus (1836-1919), nista imela otrok, je ta stranska veja Brandisov z njegovo smrtjo 14. maja 1907 izumrla. ${ }^{121}$

${ }^{116}$ P. Erik Brandis, DJ, je bil kar 37 let profesor naravoslovja na jezuitski gimnaziji v Travniku v Bosni in Hercegovini, izjemnega pomena pa so njegove raziskave na področju botanike. Gl. Hilda RITER, Prenos »Brandisovog herbara « iz Travnika u Sarajevo (Prinova botaničke zbirke Biološkog instituta), Godišnjak Biološkog instituta u Sarajevu, 4/1, 1951, str. 115-119; Čedomil ŠILIĆ, Erik (Erich) Brandis (1834.-1921.). Kao prosvetitelj, pedagog, znanstvenikprirodoslovac i muzealac, Travnik-Sarajevo 2007.

117 Natančneje o prodaji: Lilijana URLEP, Betnava pod lavantinsko škofijo, Dvorec Betnava 2018 (op. 5), str. 168-170.

118 JANISCH 1878 (op. 96), str. 496.

119 O Antonu Adrijanu kot deželnem glavarju gl. KRAMP 2002 (op. 90), str. 524-527. Prim. HIRN 1892 (op. 3), str. 12.

${ }^{120}$ O prodaji Slivnice gl. Josef Andreas JANISCH, Topographisch-statistisches Lexikon von Steiermark mit historischen Notizen und Anmerkungen, 3, Graz 1885, str. 831 (z napačno navedbo prodajalčevega osebnega imena: Ferdinand, pravilno Anton Adrijan).

${ }^{121}$ StLA, Lazarini, Familie, K. 7, H. 162, Brandis, rodovnik rodbine Brandis; ZAL, SI ZAL LJU/0340, Zbirka plemiških genealogij Ludvika Lazarinija, šk. 5, Brandis, 102. Posest Antona Adrijana je dedoval Karel grof Brandis (18561925), sin Antonovega bratranca Ferdinanda. Prim. ZAL, SI ZAL LJU/0340, Zbirka plemiških genealogij Ludvika Lazarinija, šk. 5, Brandis, 102. 


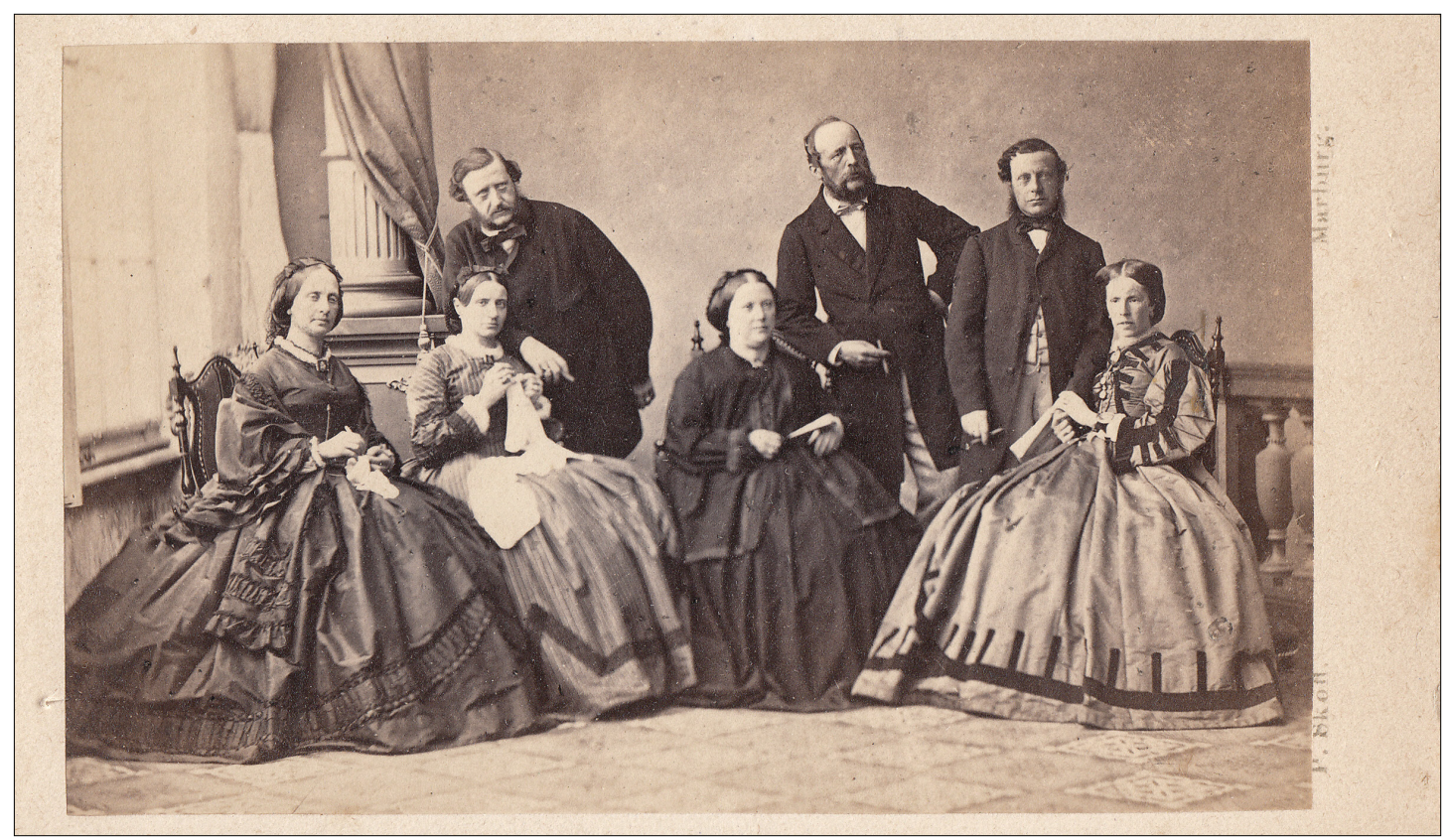

20. Družinska fotografija Brandisov (s Ferdinandom grofom Brandisom skrajno desno), ok. 1860

Posest Henrika Adama je podedoval njegov najstarejši sin Ferdinand (1819-1904) (sl. 20), ki se je 22. septembra 1846 poročil s Sofijo, roj. grofico Fünfkirchen (1829-1904), s katero je imel sedem otrok. ${ }^{122}$ V Ferdinandovem času je prišlo do enega najbolj daljnosežnih posegov v stavbno tkivo mariborskega mestnega gradu, ki je imel podobno kot nekatere prezidave v času njegovega očeta vzrok v naraščajočem mestu. Ob gradnji stavbe Višje realke (danes Prva gimnazija Maribor, Wilhelm Bücher, 1871-1873) so mestne oblasti izrazile željo po ulici, ki bi preko dvorišča mestnega gradu povezala staro mestno jedro s trgom, ki se je formiral severno od gradu, pred stavbo Višje realke. Ferdinand je na to pristal in tako je bila leta 1871 na območju dotedanjega dvorišča vzpostavljena sedanja Grajska ulica. Ob tej priliki je dal Ferdinand ob novonastali ulici kot zaključek severnega trakta gradu postaviti triosen podaljšek severnega trakta ter nov trinadstropni stolp. ${ }^{123} \mathrm{~V}$ tistih časih nedvomno dobrodošel urbanistični poseg pa $\mathrm{z}$ vidika stavbne substance mariborskega mestnega gradu brez dvoma predstavlja slabo rešitev. $\mathrm{Ne}$ le, da se je obseg gradu zaradi nove ulice zmanjšal na velikost srednjeveškega gradu (tj. na velikost pred barokizacijo), saj je bilo upravno poslopje ločeno od same stavbe gradu (in kasneje temeljito prezidano, $s$ čimer je izgubilo prvotno podobo), odstranjen je bil tudi zgoraj omenjeni poznobaročni dvoriščni portal, predvsem pa sta se loretska kapela in poznobaročni stopniščni trakt, ki sta bila prej na dvorišču, znašla na sami ulici, kjer učinkujeta nenavadno in sta v zadnjih letih tudi priči različnim vandalizmom. ${ }^{124}$

${ }^{122}$ StLA, Lazarini, Familie, K. 7, H. 162, Brandis, rodovnik rodbine Brandis; ZAL, SI ZAL LJU/0340, Zbirka plemiških genealogij Ludvika Lazarinija, šk. 5, Brandis, 104, 124. Po Sofiji grofici Brandis se je do konca prve svetovne vojne imenoval trg, ki se je po podrtju mestnega obzidja in opustitvi grajskega vrta, slednjega je grofica 1863 prodala mestni občini, formiral vzhodno od mestnega gradu (Sophienplatz; današnji Trg svobode). Prim. JANISCH 1885 (op. 80), str. 167; CURK 2007 (op. 33), str. 62.

${ }^{123}$ CURK 1959 (op. 33), str. 34; CURK 1988 (op. 33), str. 124; CURK 2007 (op. 33), str. 62. Prim. VRIŠER 1969 (op. 33), str. 9-10; STOPAR 1990 (op. 33), str. 80. V stolpu je danes uprava Pokrajinskega muzeja Maribor.

${ }^{124} \mathrm{O}$ urbanističnih posledicah vzpostavitve Grajske ulice gl. Marjeta CIGLENEČKI, Urbanistična podoba Maribora v 19. in 20. stoletju, Studia Historica Slovenica, 6/2-3, 2006, str. 536. 
Vzrok, da je Ferdinand pristal na takšno rešitev, tiči nemara v dejstvu, da se je podobno kot bratranec Anton Adrijan tudi sam odločil prodati svoje štajerski posesti in se preseliti na Tirolsko. Do prodaje nekdanjih gospostev Maribor in Gornji Maribor je tako prišlo komaj nekaj let za usodnim urbanistično-arhitekturnim posegom, leta $1876 .{ }^{125} \mathrm{Z}$ omenjenimi prodajami se je končalo skoraj sto štirideset let trajajoče delovanje grofov Brandis na Štajerskem, ki je za seboj pustilo tudi mnoge materialne priče. S prodajo štajerskih posestev so se aktivnosti rodbine osredotočile na Južno Tirolsko, kjer Ferdinandovi neposredni potomci uspešno delujejo še danes.

Tirolski grofje Brandis, ki so v 18. in večjem delu 19. stoletja imeli v lasti tudi več štajerskih posestev, brez dvoma sodijo med najpomembnejše plemiške umetnostne naročnike pri nas. $\mathrm{Ne}$ le, da so zaslužni za nekatere ključne baročne spomenike, na primer barokizacijo mariborskega mestnega gradu in dvorca Betnava. Tudi v 19. stoletju, ko plemstvo ni več sodilo med vodilne umetnostne naročnike, so ohranili svojo naročniško vnemo, kar se med drugim kaže pri dvorcu Slivnica, enem najpomembnejših historističnih dvorcev na Slovenskem, ali pa pri markantni kapeli na mariborski Piramidi, ki predstavlja eno ključnih mestnih dominant. S pričujočim preglednim prispevkom je bilo postavljeno ogrodje za nadaljnje raziskave, ki bi se morale osredotočiti zlasti na naročniško najbolj dejavne predstavnike rodbine Brandis, s čimer bi brez dvoma prišli še do marsikaterega novega spoznanja o plemiškem naročništvu v baroku in 19. stoletju na Štajerskem, pa tudi v Habsburški monarhiji. ${ }^{126}$

${ }^{125}$ CURK 1988 (op. 33), str. 121.

${ }^{126}$ Raziskave za pričujoči prispevek so potekale na Umetnostnozgodovinskem inštitutu Franceta Steleta ZRC SAZU v okviru raziskovalnega programa Slovenska umetnostna identiteta v evropskem okviru (P6-0061) in na Filozofski fakulteti Univerze v Mariboru v okviru raziskovalnega projekta Umetnostna reprezentacija plemstva: naročništvo na Štajerskem v zgodnjem novem veku (J6-7410); oba sofinancira Javna agencija za raziskovalno dejavnost Republike Slovenije iz državnega proračuna. Za dostop do Brandisovega rodbinskega arhiva in posredovanje arhivskih virov se najlepše zahvaljujem Jakobu grofu Brandisu, za gostoljubje Ferdinandu grofu Brandisu, za koristne nasvete in pomoč pri pripravi članka pa dr. Tini Košak, dr. Mihi Preinfalku, dr. Poloni Vidmar in dr. Barbari Žabota. 


\title{
The Counts of Brandis - Art Patrons in Styria
}

\author{
Summary
}

The Counts of Brandis, who were first mentioned as early as the $12^{\text {th }}$ century, were one of the most prominent Tyrolean noble families. Seven Tyrolean provincial governors (more than from any other family from Tyrol) and two Tyrolean governors came from the family that was elevated to the rank of Counts in 1641, while several of their representatives had important functions at the imperial court and others had remarkable military careers. The Counts of Brandis were also known for their piety. Numerous members of the family were priests, monks and nuns, and they frequently offered financial aid to the Catholic Church. The history and genealogy of the Brandis family is well researched, however, their art patronage in Tyrol and in other Austrian provinces where they lived and worked, has not yet been studied. Thus, the present paper is the first attempt at presenting the art patronage of the Counts of Brandis in Styria, where they owned properties in the $18^{\text {th }}$ and a large part of the $19^{\text {th }}$ century.

At the beginning of the $17^{\text {th }}$ century, the Brandis family split into two lines; the older or the Austrian line, whose estates were in Lower Austria (Rodaun, Siebenhierten, for some time Kottingbrunn as well), and the younger or Tyrolean line, which owned lands in the "Brandis homeland", in the Adige valley in southern Tyrol. In 1725, Franz Jakob Count of Brandis (1677-1746), from the Austrian line, and his sister Katharina, married Countess of Drašković (died in 1751), inherited several estates from the Counts of Khisl in Styria from Maria Eleonora Countess of Orsini-Rosenberg, née Countess of Khisl. Owing to the fact that the two new owners soon had different views on how to manage the hugely indebted inheritance, Franz Jakob sold both his estates in Lower Austria and in 1737 paid off his sister, with whom he became the owner of the estates Maribor (Marburg a. d. Drau), Gornji Maribor (Obermarburg), Betnava (Windenau) with the incorporated Gromperk (Grienberg), and Miklavž na Dravskem polju (St Nikolai). This was the beginning of the 140 year-long stay of this important family in Styria, of which numerous material witnesses remind us.

Franz Jakob held several important functions in Vienna, which is why he was not active as an art patron in Styria. His son Heinrich Adam (1715-1790) was far more engaged. Soon after receiving his inheritance, he sold the Miklavž estate and bought a house on Burggasse in Graz and, more importantly, he began a thorough reconstruction of the Maribor Town Castle, which was the main residence of the family in Styria. In this way, the castle obtained a representative Baroque staircase (by Josef Hofer, perhaps in collaboration with Joseph Hueber, 1747-1749) in place of an old annexed building with a stair-turret, and, simultaneously, the courtyard portal received a late-Baroque gable. In 1751, Heinrich Adam commissioned the construction of an additional floor above the bastion, which he bought from the town and in which he had arranged his own apartment. At the same time, an oratory was added to the Loreto chapel and the north- and south-eastern castle towers were demolished. This was followed by the decoration of the interior, particularly the painting of the central field on the ceiling of the central hall (Joseph Michael Gebler, 1763). Thus, with Heinrich Adam's constructional changes, the complex of Maribor Town Castle was extended and obtained a Baroque appearance.

The abandoned Gornji Maribor castle suffered a different fate; it was demolished in 1784 by Heinrich Adam. In its place, a Classicist pyramid was built, an important dominant of the town, after which the hill is still named. The third large commission was the baroque renovation of the Betnava Manor, which was carried out somewhere between 1756 and 1781 after the plans by Maribor architects Josef Hofer and Johann Nepomuk Fuchs. It is possible that architect Joseph Hueber from Graz participated as well. Owing 
to his ventures as a patron, Heinrich Adam had a much more important role that had been ascribed to him in older literature, as it is precisely because of the baroque renovation of the Maribor Town Castle and the Betnava Manor that he is one of the most notable aristocratic patrons in Styria.

Heinrich Adam died without having any male heirs, with which the Austrian line of the Brandis family died out. For this reason, before passing away, he adopted his relative from the Tyrolean line, Johann Baptist (1751-1812), who moved to Styria at the request of his „uncle. During his time, the property was somewhat reduced in size, since he had sold the house in Graz. He tried to buy the Frajštajn (Freistein) seigneury but was unsuccessful. The time of Johann Baptist, marked with the Napoleonic wars, was not optimal for constructional and art ventures, the only known construction alterations were the removal of the northwestern tower and the pediment of the southern façade of the Maribor Town Castle (before 1795).

In contrast to his ancestors, Johann Baptist did not leave a will, thus, after his death his sons Heinrich Adam and Clemens divided his properties in Styria, while they administered the properties in Tyrol together. Heinrich Adam (1787-1869) inherited the Maribor and Gornji Maribor seigneuries, and he soon expanded his property by buying the house on Herrengasse in Graz and by inheriting the Murstätten estate. However, he sold both in 1822. Similar to his „Baroque“ namesake, he also made alterations to the appearance of the Maribor Castle, however, they were connected particularly to the urban needs of the growing Maribor. For this reason, in 1827, when the Graz (Ulrich's) town door was demolished, the southern façade of the castle was elongated, and in 1843, an additional floor was built on top of the administrative building for the needs of estate administration. In 1821, when lightning completely destroyed the pyramid on the pyramid hill above the town, Heinrich Adam commissioned the construction of a Classicist chapel of the Immaculate in its place.

Heinrich Adam's younger brother, Clemens (1798-1863), inherited Betnava and Gromperk from his father. In 1828, he expanded the property by buying Frajštajn (Freistein), and in 1847, Slivnica (Schleinitz), Ravno polje (Ebensfeld) and Šentjanž na Dravskem polju (St. Johann am Draufelde). He was the holder of several political functions (governor and provincial governor of Tyrol, Obersthofmeister of Emperor Ferdinand I), while he was also important as an art patron. In Tyrol and Bohemia, his commissions originated primarily from carrying out his functions, while in Styria, they were exclusively of a private nature. In 1834, when his wife Adrienne, née Countess Des Enffans d'Avernas, suddenly passed away, he commissioned the erection of a burial chapel at the Magdalene cemetery in Maribor. In 1891, when the cemetery was abandoned, the chapel was demolished. His son Anton Adrian commissioned the erection of a new chapel made of the stones of the first one in the Pobrežje cemetery.

The reconstruction of the Slivnica Manor, which Clemens chose as his residence after he retired from politics, is undoubtedly his most important commission in Styria. Thus, between 1859 and 1863, Maribor building master Ferdinand Brodback thoroughly redesigned the mansion in Neo-Gothic style after the plans by an unknown architect (likely from Vienna). Owing to this exhaustive architectural alteration, alongside the Viltuš (Wildhaus) and Jelše (Erlachstein) Manors, the Slivnica Manor is one of the most important Historicist manors in Slovenia.

Heinrich Adam and Clemens were in contact with the leading Nazarene painter in Vienna, Leopold Kupelwieser, who contributed paintings for the burial chapel at the Magdalene cemetery (1835) and the chapel of the Slivnica Manor (1862), as well as for the parish church in Smlednik (Flödnig) in Carniola (1847), which was commissioned by Heinrich Adam's daughter Anna Maria, married Baroness Lazarini (1818-1888). Through Kupelwieser, the Brandis family came into contact with the leading Viennese architect Karl Rösner, the author of the parish church in Smlednik (1847-1849, consecrated in 1851) and the chapel of the Sisters of Mercy in Pinkafeld in Burgenland (1854-1855), for which Leopoldine Brandis, a member of the order of the Daughters of Christian Love (christened name Maria Josepha, 1815-1900), also the daughter of Heinrich Adam, is responsible.

After the death of Heinrich Adam, his estate was inherited by his son Ferdinand (1819-1904), in the time of whom one of the most extensive alterations to the Maribor Town Castle was carried out: the 
construction of the street across the castle courtyard (1871). Consequently, the width of the building was reduced to the size of a medieval castle, the late-Baroque courtyard portal was demolished, while the Loreto chapel and the staircase were now facing the street. Only a few years later, in 1876, Ferdinand sold all his properties in Styria and returned to Tyrol. In 1880, Clemens' son and heir Anton Adrian (18321907), who was the Tyrolean provincial governor like his father and who was not interested in having properties in Styria, likely owing to its remoteness from other family estates, did something similar. With this ended the almost century and a half long period of the Brandis family in Styria, which was extremely important from perspective of art patronage. 


\section{APPARATUS}





\section{IZVLEČKI IN KLJUČNE BESEDE} ABSTRACTS AND KEYWORDS

\author{
Marjeta Ciglenečki \\ Franc Ignac grof Inzaghi, ptujski nadžupnik in dekan \\ ter češčenje sv. Viktorina, prvega po imenu znanega \\ petovionskega škofa
}

1.01 Izvirni znanstveni članek

Franc Ignac grof Inzaghi (1691-1768) je bil nadžupnik in dekan ptujske župnijske cerkve sv. Jurija od leta 1731 do smrti. Članek želi osvežiti védenje o grofovem prispevku $\mathrm{k}$ videzu in opremi cerkve, opozarja pa tudi na Inzaghijevo prizadevanje, da bi pridobil papeževo dovoljenje za češčenje sv. Viktorina, prvega latinskega eksegeta in prvega po imenu znanega škofa $v$ Petovioni, ki je umrl mučeniške smrti leta 303. Prispevek podaja stanje raziskav o zgodnjem krščanstvu v Petovioni, predstavlja sv. Viktorina in rodbino Inzaghi, osredotoča pa se na ureditev kapele Žalostne Matere božje in stropno poslikavo v kapeli, delo ptujskega slikarja Franca Antona Pachmayerja in njegovega pomočnika Antona Lerchingerja (1741). Avtorica je skušala prepoznati ikonografski program poslikave, ki jo je primerjala $\mathrm{z}$ Viktorinovim komentarjem Apokalipse. Podala je hipotezo, da so v južnem stranskem polju upodobljeni sv. Viktorin in več oseb iz Stare zaveze, o katerih je razpravljal sv. Viktorin.

Ključne besede: poznoantična Petoviona, Ptuj, sv. Viktorin, češčenje svetnikov, In Apocalypsin, Franc Ignac grof Inzaghi (1691-1768), župnijska cerkev sv. Jurija, kapela Žalostne Matere božje, Franc Anton Pachmayer, Anton Jožef Lerchinger

\author{
Marjeta Ciglenečki \\ Franz Ignaz Count of Inzaghi, Ptuj Parish Archpriest \\ and Dean, and the Veneration of St Victorinus, \\ First Bishop of Poetovio Known by Name \\ 1.01 Original scientific article
}

From 1731 until his death, Franz Ignaz Count of Inzaghi (1691-1768) was the archpriest and dean of the parish church of St George in Ptuj. The paper aims to refresh our knowledge of the Counts' contribution to the appearance and furnishings of the church, while it also points out Inzaghi's efforts to obtain the Pope's permission for the veneration of St Victorinus, the first Latin exegete and the first bishop in Poetovio known by name, who died as a martyr in $303 \mathrm{AD}$. The contribution presents the current state of research on Early Christianity in Poetovio, St Victorinus and the Inzaghi family, while it focuses on the arrangement of the chapel of Our Lady of Sorrows and the ceiling painting in the chapel, the work of Ptuj painter Franz Anton Pachmayer and his assistant Anton Lerchinger (1741). The author attempted to recognize the iconographic program of the painting, which she compared to St Victorinus' comment of the Apocalypse. She set a hypothesis that St Victorinus and several people from the Old Testament, whom he discussed, are depicted in the southern side field.

Keywords: late antique Poetovio, Ptuj, St Victorinus, veneration of saints, In Apocalypsin, Franz Ignaz Count of Inzaghi (1691-1768), parish church of St George, chapel of Our Lady of Sorrows, Franz Anton Pachmayer, Anton Josef Lerchinger 


\author{
Renata Komić Marn \\ Portreti Eleonore Marije Rozalije kneginje Eggenberg, \\ rojene princese Liechtenstein
}

\subsection{Izvirni znanstveni članek}

Narodna galerija v Ljubljani hrani portret plemkinje, ki je nekdaj veljala za Turjačanko, iz druge polovice 17. stoletja. Na podlagi primerjalne analize je bilo mogoče v dami na sliki prepoznati Eleonoro Marijo Rozalijo kneginjo Eggenberg (1647-1703). V prispevku so predstavljeni rezultati zadnjih raziskav o provenienci, času nastanka in avtorstvu kneginjinih že znanih portretov in še enega novo identificiranega. Posebna pozornost je namenjena javnemu delovanju portretiranke in njene$\mathrm{mu}$ vplivu na umetnostna naročila v dvorcu Eggenberg pri Gradcu.

Ključne besede: portreti, slikarstvo, oblačilna moda, umetnostno naročništvo, Eleonora Marija Rozalija Eggenberg (1647-1703), Almanach, Herman Verelst (1640/41-1702), Johann Ulrich Mayr (1629-1704)

\section{Susanne König-Lein \\ Portretni galeriji v graškem dvoru in dvorcu Karlau $v$ 17. in 18. stoletju}

\subsection{Izvirni znanstveni članek}

$\mathrm{V}$ prispevku sta na podlagi sočasnih pisnih virov raziskani portretni zbirki, ki sta jih okrog leta 1600 zasnovala nadvojvoda Karel II. in nadvojvodinja Marija in sta bili do 18. stoletja v graškem dvoru in dvorcu Karlau pri Gradcu. Predstavljeni so serije portretov, umetniki in dela, ki so ohranjena v Umetnostnozgodovinskem muzeju na Dunaju. Obravnavani so vzroki za naročilo izjemno številnih otroških portretov. Poleg tega je analizirana vloga portretnih serij rimskih cesarjev in kostumskih slik.

Ključne besede: slikarska galerija, renesančni portreti, Gradec, nadvojvoda Karel II. (1540-1590), nadvojvodinja Marija Bavarska (1551-1608), Habsburžani, Cornelis Vermeyen, Jakob de Monte, Giovanni Pietro de Pomis (ok. 1565-1633)

\section{Renata Komić Marn}

Portraits of Eleonora Maria Rosalia Princess of Eggenberg, née Liechtenstein

1.01 Original scientific article

The National Gallery in Ljubljana keeps a portrait of a noblewoman from the second half of the $17^{\text {th }}$ century, once known as a noblewoman from the House of Auersperg. Based on a comparative analysis, we can identify the sitter as Eleonora Maria Rosalia Princess of Eggenberg (1647-1703). In the paper, the results of the latest research on provenance, the time of origin and the authorship of the already known portraits of the princess are presented, as well as the authorship of a newly identified portrait. Special attention is placed on the public workings of the portrayed and her influence on art commissions at the Eggenberg Manor near Graz.

Keywords: portraiture, painting, history of costume, art patronage, Eleonora Maria Rosalia Eggenberg (1647-1703), Almanach, Herman Verelst (1640/411702), Johann Ulrich Mayr (1629-1704)

\section{Susanne König-Lein}

The Habsburg Portrait Galleries in Graz Castle and Karlau Manor in the $17^{\text {th }}$ and $18^{\text {th }}$ Centuries

1.01 Original scientific article

The article discusses portrait galleries established by Archduke Charles II and Archduchess Maria around 1600 and stored in Graz Castle and Karlau Castle near Graz until the $18^{\text {th }}$ century. The collections are analysed based on published archival sources. Several unique portrait series are presented, as well as the artists and the works of art, which are now kept in the Kunsthistorisches Museum in Vienna. The commissioners' practices and collecting endeavours associated with the accumulation of family portraits are explained. In addition, the article discusses the role of the portrait series of Roman emperors and a series of costume paintings, which were also included in the collection.

Keywords: portrait gallery, Renaissance portraiture, Graz, Archduke Charles II of Inner Austria (1540-1590), Archduchess Maria of Inner Austria (1551-1608), House of Habsburg, Cornelis Vermeyen, Jakob de Monte, Giovanni Pietro de Pomis (c. 1565-1633) 


\author{
Franci Lazarini \\ Grofje Brandis - umetnostni naročniki na Štajerskem
}

\subsection{Pregledni znanstveni članek}

Prispevek govori o umetnostnem naročništvu grofov Brandis, tirolske plemiške rodbine, ki je v 18. in prvih treh četrtinah 19. stoletja imela v lasti več posestev na Štajerskem. Avtor analizira pomen članov naročniško precej aktivne rodbine, ki je med drugim zaslužna za barokizacijo mariborskega mestnega gradu in dvorca Betnave, porušitev gradu Gornji Maribor in postavitev klasicistične piramide ter kasneje kapele Brezmadežne na njegovem mestu, temeljito prezidavo dvorca Slivnica in izgradnjo grobne kapele na pobreškem pokopališču.

Ključne besede: plemstvo, umetnostno naročništvo, grofje Brandis, Štajerska, barok, klasicizem, historizem, 18. stoletje, 19. stoletje

\section{Edgar Lein \\ Contraphe der abgeleibten fürstlichen Bischöff zu Seccau. K portretni galeriji sekovskih škofov v gradu Seggau}

1.01 Izvirni znanstveni članek

V škofovski galeriji v reprezentančnih prostorih gradu Seggau je razstavljenih 58 dopasnih portretov sekovskih škofov. Portretna galerija je bila prvič omenjena v inventarju, ki je bil spisan leta 1675, v času škofa Venclja Viljema Hofkirchna (1670-1679). Portreti so bili prvotno nameščeni v prostoru, imenovanem velika dvorana (großer Saal) ali škofova soba (Bischofszimmer). Okrog leta 1830 je mogoče škofovo sobo locirati v prvo grajsko nadstropje. Med letoma 1835 in 1867 so portrete prenesli v dve sobi v drugem nadstropju, kjer so še sedaj. Vzor za škofovsko portretno galerijo so bile freske v škofovski kapeli samostana Seckau, ki jo je zasnoval škof Martin Brenner. Galerija je primerljiva $\mathrm{z}$ drugimi škofovskimi portretnimi galerijami v Salzburgu, Augsburgu, Dillingenu, Kroměřížu in Šentandražu (danes v Mariboru). Paradigmatični za portretne galerije so trije temeljni koncepti: tradicija, nasledstvo in memoria.

Ključne besede: portret, škofovska portretna galerija, sekovski škofje, grad Seggau, augsburški škofje, salzburški nadškofje, olomouški škofje, lavantinski škofje, reprezentančni prostori, škof Martin Brenner (1548-1616)

\author{
Franci Lazarini \\ The Counts of Brandis - Art Patrons in Styria
}

1.02 Review article

The paper deals with the art patronage of the Counts of Brandis, a noble family from Tyrol that owned numerous estates in Styria in the $18^{\text {th }}$ and the first three quarters of the $19^{\text {th }}$ century. The author analyses the importance of the members of this family that was very active in the field of art patronage; among other things, it was responsible for the Baroque renovation of the Maribor (Marburg a. d. Drau) Castle and the Betnava (Windenau) Manor, the demolition of the Gornji Maribor (Obermarburg) castle, the erection of the Classicist pyramid and the subsequent chapel of the Immaculate, which was later erected in its place, a thorough reconstruction of the Slivnica (Schleinitz) Manor, and the construction of the burial chapel at the Pobrežje cemetery.

Keywords: nobility, art patronage, Counts of Brandis, Styria, Baroque, Classicism, Historicism, $18^{\text {th }}$ century, $19^{\text {th }}$ century

\section{Edgar Lein \\ Contraphe der abgeleibten fürstlichen Bischöff zu Seccau. On the Portrait Gallery of Seckau Bishops in Seggau Castle}

1.01 Original scientific article

Nowadays, 58 half-length portraits of the bishops of Seckau are included in an episcopal gallery in the representation rooms of Seggau Castle. The portrait gallery was first mentioned in an inventory, written in 1675 under the reign of bishop Wenzel Wilhelm von Hofkirchen (1670-1679). At the beginning, these portraits were presented in a room called the great hall (großer Saal) or the bishop's room (Bischofszimmer). Around 1830 the bishop's room was located on the first floor of the castle. Between 1835 and 1867 the portraits were moved into the two rooms on the second floor where they are today. The model for this type of gallery can be found in the bishop's chapel (Bischofskapelle) in Seckau Abbey, founded by Bishop Martin Brenner. The gallery is similar to other portrait galleries of bishops in Salzburg, Lavant, Augsburg, Dillingen, Kroměříž, St Andrä (now in Maribor). It is a paradigm for the three fundamental concepts of portrait galleries: tradition, legacy and memoria.

Keywords: portrait, bishops' portrait gallery, Bishops of Seckau, Seggau Castle, Bishops of Augsburg, Archbishops of Salzburg, Bishops of Olomouc, Bishops of Lavant, representational rooms, bishop Martin Brenner (1548-1616) 


\section{Polona Vidmar}

Theatrum genealogicum. Rodovniki grofov Herberstein in Dietrichstein kot sredstvo plemiške reprezentacije

\subsection{Izvirni znanstveni članek}

$\mathrm{V}$ prispevku so obravnavane slike in grafike rodovnikov rodbin Herberstein in Dietrichstein, ki so nastale v 17. in 19. stoletju. Vizualizacije genealogij so postavljene v kontekst sočasnih zgodovinskih del, ki so bila publicirana po naročilu obravnavanih plemiških rodbin, pri čemer je poudarjena njihova reprezentativna vloga. Analizirane so upodobitve grbov, portretov, simboličnih figur in predmetov, vedut in historičnih prizorov, ki dopolnjujejo rodovna debla, veliko pozornosti je posvečene tudi napisom na slikah in grafikah. Prispevek prinaša nove ugotovitve o historiografih, ki so po naročilu plemstva publicirali genealoška dela in snovali likovne upodobitve genealoškega vedenja, zlasti o cesarskem historiografu Dominiku Frančišku Kalinu. V prispevku sta prvič objavljeni Kalinovi genealogiji velikega formata, ki ju je v letih 1672 in 1675 naslikal po naročilu uspešnega dvorjana Gundakarja grofa Dietrichsteina.

Ključne besede: genealogija, rodovnik, plemiška reprezentacija, grofje Herberstein, grofje in knezi Dietrichstein, Dominik Frančišek Kalin von Marienberg (16241683), Jacob Bruynel

\section{Polona Vidmar}

Theatrum genealogicum. Family Trees of Counts of

Herberstein and Dietrichstein as a Means of Aristocratic Representation

\subsection{Original scientific article}

The paper discusses the paintings and graphic prints of the genealogies of the Herberstein and Dietrichstein families that were made in the $17^{\text {th }}$ and $19^{\text {th }}$ centuries. The visualizations of the genealogies are put into the context of concurrent historical works that were published under commission from the discussed noble families, where their representative role was put in the forefront. The depictions of coats-of-arms, portraits, symbolic figures and objects, vedute and historical scenes, which complete the family trees, are analysed, with a great deal of attention placed on the inscriptions on paintings and graphics. The paper offers new findings on historiographers who published genealogical works on the commissions of the nobility and designed visual depictions of the genealogical knowledge, especially about the imperial historiographer Dominicus Franciscus Calin. Moreover, the paper introduces hitherto unpublished Calin's large format genealogies, which he painted in 1672 and 1675 under commission of successful courtier Gundakar Count Dietrichstein.

Keywords: genealogy, genealogical tree, aristocratic representation, House of Herberstein, House of Dietrichstein, Dominicus Franciscus Calin von Marienberg (1624-1683), Jacob Bruynel 


\section{SODELAVCI}

\section{CONTRIBUTORS}

Izr. prof. dr. Marjeta Ciglenečki

Krempljeva 9

SI-2250 Ptuj

marjeta.ciglenečki@gmail.com

Dr. Renata Komić Marn

ZRC SAZU, Umetnostnozgodovinski inštitut Franceta Steleta

Novi trg 2

SI-1000 Ljubljana

renata.komic@zrc-sazu.si

Dr. Susanne König-Lein

Körblergasse 59

A-8010 Graz

koenig-lein@aon.at

Doc. dr. Franci Lazarini

Univerza v Mariboru, Filozofska fakulteta

Koroška cesta 160

SI-2000 Maribor

franci.lazarini@um.si

Prof. dr. Edgar Lein

Körblergasse 59

A-8010 Graz

edgar.lein@gmx.at

Izr. prof. dr. Polona Vidmar

Univerza v Mariboru, Filozofska fakulteta

Koroška cesta 160

SI-2000 Maribor

polona.vidmar@um.si 



\section{VIRI ILUSTRACIJ \\ PhOTOGRAPHiC CREDITS}

\section{Marjeta Ciglenečki}

1-3, 5, 6: W. Schmid, Ptujske krščanske starosvetnosti, Časopis za zgodovino in narodopisje,

31/3-4, 1936, str. 99, 103, 104, sl. 16.

4: @ Zgodovinski arhiv Ptuj (foto: Marjeta Ciglenečki).

7: Drobtinice, 3, 1848.

10-14: Foto: Marjeta Ciglenečki.

8, 9, 15, 16, 18, 19, 22-38: @ ZRC SAZU, Umetnostnozgodovinski inštitut Franceta Steleta, Ljubljana (foto: Andrej Furlan).

17, 20, 21: @ Pokrajinski muzej Ptuj Ormož, Ptuj (foto: Boris Farič).

\section{Renata Komić Marn}

1, 6: ๑ Narodna galerija, Ljubljana (foto: Bojan Salaj).

2: (๑) Narodna galerija, Ljubljana, fototeka.

3-4, 7-8, 13-15: ๑ Grad in dvorec Český Krumlov, Český Krumlov.

5: () Ministrstvo RS za kulturo, Informacijsko-dokumentacijski center (foto: France Stele).

9-10: Vnderschidliche geistliche vnd weltliche, weibliche, vnd mannliche Contrafait /.../

Ljubljana-Zagreb 2008 (Iconotheca Valvasoriana, 12).

11-12: ( $)$ Schloss Eggenberg, Universalmuseum Joanneum, Gradec.

16: ๑ ZRC SAZU, Umetnostnozgodovinski inštitut Franceta Steleta, Ljubljana (foto: Andrej Furlan).

17: Freywillig-auffgesprungener Granat-Apffel, http://diglib.hab.de/drucke/7-8f-726/start.

htm?image $=00005$.

\section{Franci Lazarini}

1, 18: @ ZRC SAZU, Umetnostnozgodovinski inštitut Franceta Steleta, Ljubljana (foto: Franci Lazarini).

2, 8, 10, 19-20: Arhiv rodbine Lazarini.

3-5, 7, 9, 11, 16-17: @ ZRC SAZU, Umetnostnozgodovinski inštitut Franceta Steleta, Ljubljana

(foto: Andrej Furlan).

6, 12-13: Igor Sapač.

14-15: @ ZRC SAZU, Umetnostnozgodovinski inštitut Franceta Steleta, Ljubljana

(foto: Simona Kostanjšek Brglez).

\section{Susanne König-Lein}

1-22: @ Kunsthistorisches Museum, Wien.

\section{Edgar Lein}

1-2, 4-5: Wolfgang Wrolli.

6: Schloß Seggau, Graz 1997, str. 75.

7, 12: Wikimedia Commons.

8: Google Books.

10, 11: @ZRC SAZU, Umetnostnozgodovinski inštitut Franceta Steleta, Ljubljana (foto: Andrej Furlan).

9, 13: Friedrich Polleroß. 


\section{Polona Vidmar}

1, 3-4, 6-8, 12: (C ZRC SAZU, Umetnostnozgodovinski inštitut Franceta Steleta, Ljubljana (foto: Andrej Furlan).

2, 16: Moravský zemský archiv v Brnĕ (foto: Polona Vidmar).

5: Der Heilige Leopold. Landesfürst und Staatssymbol, Klosterneuburg 1985.

9: E. I. Naso, Monimentum Historico-Panegyricum, Wratislaviæ 1680.

10-11: Polona Vidmar.

13: G. G. Priorato, Historia di Leopoldo Cesare, 3, Vienna 1674.

14, 17-21: Arhiv lastnika.

15: D. F. Calin, Elogia illustrium heroum, Viennæ 1675.

22: Die Fürsten Esterházy. Magnaten, Diplomaten \& Mäzene, Eisenstadt 1995.

23: Adel im Wandel. Politik, Kultur, Konfession 1500-1700, Wien 1990. 

CIP - Kataložni zapis o publikaciji

Narodna in univerzitetna knjižnica, Ljubljana

7.074:929.7(436.4+497.4-18)

STRATEGIJE umetnostne reprezentacije štajerskega plemstva v zgodnjem novem veku = Visual representation strategies of the Styrian nobility in early modern times / [urednici Polona Vidmar, Tina Košak ; prevodi Nika Vaupotič, Polona Vidmar]. - Ljubljana : ZRC SAZU, Umetnostnozgodovinski inštitut Franceta Steleta = ZRC SAZU, France Stele Institute of Art History, 2019. - (Acta historiae artis Slovenica, ISSN 1408$0419 ; 24 / 2,2019)$

ISBN 978-961-05-0245-6

1. Vzp. stv. nasl. 2. Vidmar, Polona, 1971-

COBISS.SI-ID 303171328

Vse pravice pridržane. Noben del te izdaje ne sme biti reproduciran, shranjen ali prepisan v kateri koli obliki oz. na kateri koli način, bodisi elektronsko, mehansko, s fotokopiranjem, snemanjem ali kako drugače, brez predhodnega dovoljenja lastnika avtorskih pravic (copyright).

All rights reserved. No part of this publication may be reproduced, stored in a retrieval system or utilized in any form or by any means, electronic or mechanical, including photocopying, recording or otherwise, without prior permission of the copyright owner.

Za avtorske pravice reprodukcij odgovarjajo avtorji objavljenih prispevkov.

The copyrights for reproductions are the responsibility of the authors of published papers. 
ACTA HISTORIAE ARTIS SLOVENICA 24|2 • 2019

\section{Vsebina $\cdot$ Contents}

Polona Vidmar, Strategije umetnostne reprezentacije štajerskega plemstva v zgodnjem novem veku. Predgovor • Visual Representation Strategies of the Styrian Nobility in Early Modern Times. Preface

Susanne König-Lein, Die Porträtsammlungen in der Grazer Burg und im Schloss Karlau im 17. und 18. Jahrhundert • Portretni zbirki v graškem dvoru in dvorcu Karlau v 17. in 18. stoletju

Polona Vidmar, Theatrum genealogicum. Die Stammbäume der Grafen Herberstein und Dietrichstein als Mittel adeliger Repräsentation • Theatrum genealogicum. Rodovniki grofov Herberstein in Dietrichstein kot sredstvo plemiške reprezentacije

Renata Komić Marn, Portreti Eleonore Marije Rozalije kneginje Eggenberg, rojene princese Liechtenstein • Portraits of Eleonora Maria Rosalia Princess of Eggenberg, née Liechtenstein

Edgar Lein, Contraphe der abgeleibten fürstlichen Bischöff zu Seccau. Zur Porträtgalerie der Seckauer Bischöfe in Schloss Seggau • Contraphe der abgeleibten fürstlichen Bischöff zu Seccau. K portretni galeriji sekovskih škofov v gradu Seggau

Marjeta Ciglenečki, Franz Ignaz Count of Inzaghi, Ptuj Parish Archpriest and Dean, and the Veneration of St Victorinus, First Bishop of Poetovio Known by Name • Franc Ignac grof Inzaghi, ptujski nadžupnik in dekan ter češčenje sv. Viktorina, prvega po imenu znanega petovionskega škofa

Franci Lazarini, Grofje Brandis - umetnostni naročniki na Štajerskem • The Counts of Brandis - Art Patrons in Styria

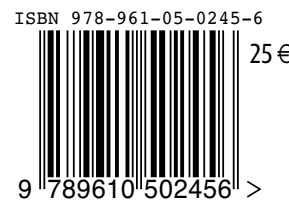

